\title{
The role of green manure nitrogen use by corn and sugarcane crops in Brazil
}

\author{
Edmilson José Ambrosano ${ }^{1 *}$, Heitor Cantarella ${ }^{2}$, Gláucia Maria Bovi Ambrosano ${ }^{3}$, \\ Fábio Luis Ferreira Dias ${ }^{1,2}$, Fabrício Rossi ${ }^{4}$, Paulo Cesar Ocheuze Trivelin ${ }^{5}$, \\ Takashi Muraoka ${ }^{5}$ \\ ${ }^{1}$ APTA, Regional Center South Pole, Piracicaba, Brazil; *Corresponding Author: ambrosano@apta.sp.gov.br \\ ${ }^{2}$ APTA, Agronomic Institute of Campinas (IAC), Campinas, Brazil \\ ${ }^{3}$ Department of Social Dentistry, State University of Campinas (UNICAMP), Piracicaba, Brazil \\ ${ }^{4}$ College of Animal Science and Food Engineering, University of São Paulo (USP), Pirassununga, Brazil \\ ${ }^{5}$ Center for Nuclear Energy in Agriculture (CENA/USP), Piracicaba, Brazil
}

Received 23 October 2013; revised 25 November 2013; accepted 5 December 2013

Copyright (C) 2013 Edmilson José Ambrosano et al. This is an open access article distributed under the Creative Commons Attribution License, which permits unrestricted use, distribution, and reproduction in any medium, provided the original work is properly cited.

\section{ABSTRACT}

Three assays were developed from April 3, 1995 to October 10, 2005. The work with corn was conducted in a greenhouse, using velvet bean (Mucuna aterrima) and sunn hemp (Crotalaria juncea) as green manure with ${ }^{15} \mathrm{~N}$ labeling of either shoots or roots, in two soils with contrasting textural classes. The mineralization of $\mathrm{N}$ from legume plants incorporated into the two soils was investigated too. This work included two green manures: velvet bean and sunn hemp, and the common bean (Phaseolus vulgaris) residues. Nitrogen from the velvet bean accounted for a greater proportion of the soil inorganic N; shoots were responsible for most of $\mathrm{N}$ accumulated. Common bean residues caused immobilization of inorganic $\mathbf{N}$. The leguminous species added were intensively and promptly mineralized, preserving the soil native nitrogen. One hundred days after emergence of the corn, velvet bean provided higher accumulation of nitrogen in the soil, higher absorption by corn plants and accumulation in the aerial part. The green manure decomposition was more intense in the medium textured soil. In this soil, highest nitrogen losses were also observed. The sugarcane (Saccharum spp.) was cultivated for five years in the field and was harvested three times; ${ }^{15} \mathrm{~N}$ recovery was evaluated in the first two harvests. The combination of inorganic fertilizer and green manure resulted in higher sugarcane yields than either $\mathrm{N}$ source applied separately; however, in the second cutting the yields were higher where sunn hemp was used than in plots with ammonium sulfate. The recovery of $\mathrm{N}$ by the first two consecutive harvests accounted for $19 \%$ to $21 \%$ of the $\mathrm{N}$ applied as sunn hemp and $46 \%$ to $49 \%$ of the $\mathrm{N}$ applied as ammonium sulfate. Very little inorganic $\mathrm{N}$ was present in the 0 $40 \mathrm{~cm}$ soil layer with both $\mathrm{N}$ sources.

Keywords: Saccharum spp.; Biological Nitrogen Fixation; ${ }^{15} \mathrm{~N}$; Isotope Technique; N-Mineralization; Mineral Nitrogen

\section{INTRODUCTION}

The incorporation of plant materials to soils, with the objective of maintaining or improving fertility for the subsequent crop, is known as green manuring. The inclusion of a legume fallow within a sugarcane cropping cycle is practiced to reduce populations of detrimental soil organisms $[1,2]$, providing nitrogen $(\mathrm{N})$ through biological fixation $[3,4]$ for weed suppression $[5,6]$.

Interest in the use of green manure's biomass has revived because of their role in improving soil quality and their beneficial $\mathrm{N}$ and non-N rotation effects [7]. Because of its nitrogen fixation potential, legumes represent an alternative for supplying nutrients, substituting or complementing mineral fertilization in cropping systems involving green manuring. This practice causes changes in soil physical, chemical and biological characteristics, bringing benefits to the subsequent crop both in smallscale cropping systems and in larger commercial areas such as those grown with sugarcane [8]. 
The area cropped with sugarcane (Saccharum spp.) in Brazil shows rapid expansion, with most of the increase for ethanol production. The area cultivated with sugarcane is now 9.6 Mha, with an increase of 5 Mha from 2000 and over 8.6 Mha of fresh sugarcane harvested per year [9]. Sugarcane crops in Brazil are replanted every five to ten years. In southeastern Brazil, the interval between the last sugarcane harvest and the new plantings occurs during the spring-summer season, under high temperature and heavy rainfall (almost $1000 \mathrm{~mm}$ in six months) [10].

According to the Köppen climate classification, Piracicaba, SP, Brazil has Cwa climate, i.e., humid subtropical, with dry winter and an average temperature in the coldest month below $18^{\circ} \mathrm{C}$ and the hottest month, exceeding $22^{\circ} \mathrm{C}$.

Green manure fertilization of the soil with legumes has been recommended before a sugarcane field is replanted. This practice does not imply on losing the cropping season, does not interfere with sugarcane germination, and provides increases in sugarcane and sugar yield, at least during two consecutive cuts [8]. Additionally, it protects the soil against erosion, prevents weed spreading and reduces nematode populations [11,12]. Legumes usually accumulate large quantities of $\mathrm{N}$ and $\mathrm{K}$, the nutrients which are taken up in the highest amounts by the sugarcane plants.

Little emphasis has been given to the effectiveness of the $\mathrm{N}$ supply by green manures [13]. The use of the ${ }^{15} \mathrm{~N}$ isotope provides precise information about the dynamics of the nitrogen in the soil-plant system.

Residue incorporation studies of legumes using ${ }^{15} \mathrm{~N}$ label indicate that $10 \%$ to $34 \%$ of the legume $\mathrm{N}$ can be recovered in the subsequent rye or wheat crop, $42 \%$ in rice, $24 \%$ recovery from Velvet bean by corn crop, around $15 \%$ of $\mathrm{N}$ recovery from sunn hemp by corn plants in no-till system, $30 \%$ by maize [14], and $5 \%$ of $\mathrm{N}$ recovery from sunn hemp by sugarcane [8], and ranged from $19 \%$ to $21 \%$ when the recovery was observed from sunn hemp by two sugarcane harvest [15].

The authors suggested that legume residue decomposition provided long-term supply of $\mathrm{N}$ for the subsequent crops, by not supplying the nutrient as an immediate source.

There are many benefits to the sugarcane crop of leguminous plants rows in rotation in maize; these include the recycling of nutrients taken up from deep soil layers by the rotational crop, which may prevent or decrease leaching losses, and the addition of $\mathrm{N}$ from biological fixation. Leguminous plants can accumulate over $5 \mathrm{t} \cdot \mathrm{ha}^{-1}$ of dry mass during a short period of time during the summer and take up large amounts of $\mathrm{N}$ and $\mathrm{K}$. Most of this $\mathrm{N}$ comes from the association of legumes with rhizobia. In this way crop rotation with legumes can replace partially or totally $\mathrm{N}$ mineral fertilization of maize $[8$, 16-18].

This study evaluated and characterized the green manure biomass production, $\mathrm{N}$ balance, the biomass mineralization of leguminous green manure and common beans residues in succession with corn and rotation with sugarcane and their effect in the soil. Their effect on stalk and sugar yield on sugarcane cv. IAC 87-3396 grown subsequently was also studied.

\section{DEVELOPMENT}

Three assays were developed during April 3, 1995 to October 10, 2005 to complete this study as following:

\subsection{The Experiments with Corn Were Carried out in Campinas, State of São Paulo, Brazil in a Green House Conditions}

The objective of this study was to evaluate $\mathrm{N}$ use in the soil-plant system from nitrogen incorporated through sunn hemp (Crotalaria juncea L.) and velvet bean $(\mathrm{Mu}-$ cuna aterrima Piper \& Tracy), with ${ }^{15} \mathrm{~N}$ labeling, and incorporated to two soils of contrasting textural classes: a clayey Eutrudox and a sandy-clayey Paleudalf, both cultivated with corn and evaluating the nitrogen mineralizetion and quantifying the transformation of the $\mathrm{N}$ from different incorporated plant residues in two soil types.

Table 1 shows the soil chemical characteristics before and after the correction followed [18].

The study was carried out in pots containing $6 \mathrm{~kg}$ air dry soil, corresponding to 5.3 and $4.7 \mathrm{~kg}$ for the of ovendried soil $\left(110^{\circ} \mathrm{C}\right)$ for the Paleudalf and the Eutrudox, respectively. All calculations in this work were based on oven-dried soil.

In the first experimental phase velvet bean and sunn hemp were sown and labeled with ${ }^{15} \mathrm{~N}$, as described by Ambrosano [20]. Nitrogen (1.2 kg) was applied to the 10 $\mathrm{kg}$ pots of soil as ammonium sulphate with $11.37{ }^{15} \mathrm{~N}$ atoms $\%$ excess, in three split-applications. The dried, labeled material harvested contained 3.177\% - 4.337\% ${ }^{15} \mathrm{~N}$ atoms, for velvet bean and sunn hemp respectively. The green manures were cut 94 days after emergence, when plants had still not gone into the flowering stage.

The incubation was performed with $39 \mathrm{~g}$ per pot of dry matter of the above-ground parts of sunn hemp and velvet bean, or common bean plant residues, equivalent to $13 \mathrm{Mg} \cdot \mathrm{ha}^{-1}$ of dry matter. For the sunn hemp and velvet bean the root parts were also added: 6.6 and $8.6 \mathrm{~g}$ per pot of root dry matter, corresponding to 2.8 and $2.2 \mathrm{Mg} \cdot \mathrm{ha}^{-1}$, respectively, for the sunn hemp and velvet bean as described in Ambrosano [20]. Soils were incubated for 36 days, before corn sowing, and monitored for nitrogen immobilization, which was not observed as described in 
Table 1. Chemical characterization of the soils used in the experiment.

\begin{tabular}{|c|c|c|c|c|c|c|c|c|c|}
\hline \multirow{3}{*}{ Soils } & $\mathrm{pH} \mathrm{CaCl}{ }_{2}$ & O. M. & $\mathrm{P}$ & K & $\mathrm{Ca}$ & $\mathrm{Mg}$ & $\mathrm{H}+\mathrm{Al}$ & $\mathrm{CEC}$ & B.S. ${ }^{*}$ \\
\hline & \multicolumn{9}{|c|}{ Original soil } \\
\hline & $0.01 \mathrm{~mol} \cdot \mathrm{L}^{-1}$ & $\mathrm{~g} \cdot \mathrm{dm}^{-3}$ & $\mathrm{mg} \cdot \mathrm{dm}^{-3}$ & & & & & & $(\%)$ \\
\hline Eutrudox & 5.5 & 32 & 23 & 4.8 & 32 & 14 & 28 & 78.8 & 64 \\
\hline \multirow[t]{2}{*}{ Paleudalf } & 4.3 & 10 & 32 & 1.7 & 6 & 1 & 28 & 36.7 & 23 \\
\hline & \multicolumn{9}{|c|}{ Eight days after liming and chemical fertilization } \\
\hline Eutrudox & 5.5 & 32 & 67 & 9.6 & 49 & 26 & 25 & 109.6 & 77 \\
\hline Paleudalf & 5.6 & 10 & 79 & 7.8 & 32 & 14 & 13 & 66.8 & 81 \\
\hline
\end{tabular}

Adapted from [14,19]. * Base saturation.

Ambrosano [20].

The incubation was carried out in a greenhouse. Soils were moistened to $70 \%$ of the pot water holding capacity.

Treatments with velvet bean and sunn hemp were further divided into two sub-treatments, one with ${ }^{15} \mathrm{~N}$ labeled above-ground parts and non-labeled roots, and another with non-labeled above-ground parts and ${ }^{15} \mathrm{~N}$ labeled roots.

For mineralization studies the treatments were sampled weekly during 49 days and inorganic $\mathrm{N}\left(\mathrm{NO}^{3-} \mathrm{N}\right.$ and $\mathrm{NH}^{4} \mathrm{~N}$ ) was extracted from a $50 \mathrm{~g}$ soil sample with 50 $\mathrm{ml}$ of $2 \mathrm{~mol} \cdot \mathrm{L}^{-1} \mathrm{KCl}$ solution. The extract was filtered and distilled with $\mathrm{MgO}$ and Devarda's alloy, as described by [21]. Distilled extracts were used to determine isotopic-N concentration by mass spectrometry by the wet method with alkaline lithium hipobromite $[22,23]$.

The AG-303 corn hybrid was sown using ten seeds per pot and soon after the emergence the pots were thinned to four plants. Thirty days after sowing pots were fertilized with $238 \mathrm{mg} \mathrm{P}\left(\mathrm{KH}_{2} \mathrm{PO}_{4}\right), 500 \mathrm{mg} \mathrm{K}\left(\mathrm{K}_{2} \mathrm{SO}_{4}\right)$, and $125 \mathrm{mg} \mathrm{Mg}$ (magnesium sulphate). That was repeated after another 30 days, except for $\mathrm{Mg}$.

Corn plants were sampled five times, at 20, 30, 40, 60 and 100 days after emergence. The plants were separated in aerial part and roots and the dry mass was determined at each age. The material was washed and dried at $60^{\circ} \mathrm{C}$ in a forced-air oven to constant weight and ground in a rotary mill with stainless steel blades.

Nitrogen concentration in plant tissues was determined using the semi-micro Kjeldahl method, including the $\mathrm{NO}^{3} \mathrm{~N}$, according to [24]. Samples for isotopic analysis were processed by the modified Dumas combustion method, according to [25], and the isotopic composition was determined using a VARIAN MAT model $\mathrm{CH} 4$ mass spectrometer [26].

Quantification of soil nitrogen was made in samples that were collected, dried at $60^{\circ} \mathrm{C}$ drying, and a subsampled, with the sub-sample dried at $110^{\circ} \mathrm{C}$ so that the results were later adjusted for dry weight. For the soil samples total-N analyses were made by digestion-distil- lation according to [21]. The isotopic $\mathrm{N}$ analyses were performed in the extract obtained for total-N determination after humid drying [22], modified according to [23].

Mineral N (nitrate and ammonium) was determined after extraction with $\mathrm{KCl}_{2} \mathrm{~mol} \cdot \mathrm{L}^{-1} \mathrm{~N}$, according to [21]. The distilled extracts were used in the ${ }^{15} \mathrm{~N}$ determinations of the same way as for those of soil total $\mathrm{N}$.

Isotopic determinations of soil mineral $\mathrm{N}$ were possible only up to the $3^{\text {rd }}$ sampling (40 DAE) because from the $4^{\text {th }}$ sampling on, the low amounts of soil mineral $\mathrm{N}$ did not allow for those analyses to be accomplished.

The soil mineral nitrogen was calculated in $\mathrm{mg} \cdot \operatorname{pot}^{-1}$ by multiplying the value in $\mathrm{mg} \cdot \mathrm{kg}^{-1}$ by the total mass of oven-dried soil contained in the pots. The total mineralized $\mathrm{N}$ was calculated for the sunn hemp, velvet bean sand without green manure treatments by adding the soil mineral $\mathrm{N}$ to those of whole plant total $\mathrm{N}$.

The $\mathrm{N}$ balance in the soil-plant system was calculated according to the nitrogen use efficiency in the whole plant, as well as that present in the soil and in the mineral $\mathrm{N}$, and the losses were determined as difference between the $\mathrm{N}$ input via manure plus that in the soil, and that which was taken up by the plant.

A completely randomized design with a factorial arrangement of treatments was used. Treatments were combinations among two legumes (green manures), two soils; two legume parts labelled with ${ }^{15} \mathrm{~N}$ (shoots and roots); five sampling times and three repetitions. The experiment also counted with an additional treatment, without green manuring, containing the two soils, five sampling times and three replications.

Treatment factor means: soil and plant parts were compared by F-test. Tukey test was used for comparisons between means of treatment factors (velvet bean, sunn hemp and without green manure) and polynomial regression was used to evaluate the effect of sampling times. The Sanest computer program was used to run the analyses.

For mineralization studies statistical analysis was with the F-test. The tukey test was used for comparison of means obtained for common bean residues, velvet bean, 
sunn hemp and control treatments. Polynomial regression was used to evaluate the effect of the incubation period.

\subsection{The Field Experiment with Sugarcane}

The field experiment with sugarcane were developed during December, 2000 to October, 2005, in a soil, classified as an Arenic Hapludult, was chemically characterized at different depths after cutting the green manure crop, before the sugarcane first planting. The soil was acidic and had low amounts of nutrients (Table 2), typical of many sugarcane growing areas. The data presented in Table 2 are only for characterizing the soil with and without the presence of sunn hemp and have not been used to make comparisons.

In the first stage of the experiment, the sunn hemp was sown and labeled with ${ }^{15} \mathrm{~N}$. The dry, labeled plant matter containing 2.412 atoms $\%$ excess ${ }^{15} \mathrm{~N}$ was obtained in December, 2000. Total dry mass was equivalent to 9.150 $\mathrm{Mg} \cdot \mathrm{ha}^{-1}$ with $21.4 \mathrm{~g} \cdot \mathrm{kg}^{-1} \mathrm{~N}$, totaling and inflow of 195.8 $\mathrm{kg} \cdot \mathrm{ha}^{-1} \mathrm{~N}$ added to the soil, as described by Ambrosano [27]. In the next step, we studied nitrogen utilization by sugarcane fertilized with sunn hemp as a green manure crop ( $\mathrm{SH}$ ) and ammonium sulfate (AS), both labeled with ${ }^{15} \mathrm{~N}$. The treatments applied were: Control; $\mathrm{AS}-{ }^{15} \mathrm{~N}$; $\mathrm{SH}-{ }^{15} \mathrm{~N}+\mathrm{AS}$; $\mathrm{SH}-{ }^{15} \mathrm{~N}$; AS- ${ }^{15} \mathrm{~N}+\mathrm{SH}$

The utilization of nitrogen by sugarcane (Saccharum spp.) fertilized with sunn hemp (Crotalaria juncea L.) and ammonium sulfate (AS) was evaluated using the ${ }^{15} \mathrm{~N}$ tracer technique, that consisted of four treatments with four replications in a randomized block design as fallow: a) control with no $\mathrm{N}$ fertilizer or green manure; b) ammonium sulfate (AS) at a rate of $70 \mathrm{~kg} \cdot \mathrm{ha}^{-1} \mathrm{~N}$; c) sunn hemp (SH) green manure; d) and sunn hemp plus ammonium sulfate $(\mathrm{SH}+\mathrm{AS})$. Microplots consisting of three rows of sugarcane 2-m long were set up in plots $\mathrm{c}$ and $\mathrm{d}$ with the ${ }^{15} \mathrm{~N}$-labeled sunn hemp.

Table 2. Soil chemical characteristics before sugarcane planting, in plots with and without green manure, at depths of $0-0.2$ and $0.2-0.4 \mathrm{~m}$.

\begin{tabular}{ccccc}
\hline & $\begin{array}{c}\text { Soil without green } \\
\text { manure crop }\end{array}$ & $\begin{array}{c}\text { Soil with green manure } \\
\text { crop (sunn hemp) } \\
\text { hemp) }\end{array}$ \\
\hline Variables & $0-0.2 \mathrm{~m}$ & $0.2-0.4 \mathrm{~m}$ & $0-0.2 \mathrm{~m}$ & $0.2-0.4 \mathrm{~m}$ \\
$\mathrm{pH}\left(0.01 \mathrm{~mol} \cdot \mathrm{l}^{-1}\right)$ & 4.1 & 4.0 & 4.5 & 4.7 \\
$\mathrm{O} . \mathrm{M} \cdot\left(\mathrm{g} \cdot \mathrm{dm}^{-3}\right)$ & 26 & 22 & 24 & 22 \\
$\mathrm{P}\left(\mathrm{mg} \cdot \mathrm{dm}^{-3}\right)$ & 3 & 14 & 6 & 6 \\
$\mathrm{~K}\left(\mathrm{mmol}_{\mathrm{c}} \cdot \mathrm{dm}^{-3}\right)$ & 0.7 & 0.5 & 0.3 & 0.3 \\
$\mathrm{Ca}\left(\mathrm{mmol}_{\mathrm{c}} \cdot \mathrm{dm}^{-3}\right)$ & 7 & 6 & 12 & 11 \\
$\mathrm{Mg}\left(\mathrm{mmol}_{\mathrm{c}} \cdot \mathrm{dm}^{-3}\right)$ & 6 & 5 & 11 & 10 \\
$\mathrm{H}+\mathrm{Al}\left(\mathrm{mmol}_{\mathrm{c}} \cdot \mathrm{dm}^{-3}\right)$ & 50 & 68 & 36 & 31 \\
$\mathrm{Al}\left(\mathrm{mmol}_{\mathrm{c}} \cdot \mathrm{dm}^{-3}\right)$ & 10 & 11 & 2 & 2 \\
\hline
\end{tabular}

Adapted from [8].
$\mathrm{N}$ was added at the rate of 196 and $70 \mathrm{~kg} \cdot \mathrm{ha}^{-1}$ as ${ }^{15} \mathrm{~N}$ labeled green manure ( $\mathrm{SH})$ and as (AS), respectively. Sugarcane was cultivated for five years and was harvested three times. ${ }^{15} \mathrm{~N}$ recovery was evaluated in the two first harvests.

Stalks yields were measured after 18 months (plantcane cycle, on 24 Aug 2002), 31 months (1st ratoon crop, on 8 Oct 2003), and 43 months after planting (2nd ratoon crop, on 20 Sep 2004). Samples consisting of ten stalks were used for the determination of apparent sucrose content (Pol) in the cane juice, according to [28]. The expressed cane juice was analyzed for Pol (apparent sucrose) by a saccharimeter. Just before harvesting of the plant cane (24 Aug 2002) and of the first ratoon (8 Oct 2003) whole plants were collected from $1-\mathrm{m}$ row of plants in the center of the microplots. Leaves and stalks were analyzed separately for determination of ${ }^{15} \mathrm{~N}$ abundance and $\mathrm{N}$ content in a mass spectrometer coupled to an $\mathrm{N}$ analyzer, following the methods described in [29].

The fraction and amount of nitrogen in the plant derived from the labeled source (Ndff) and the fraction of $\mathrm{N}$ recovery of the labeled source $(\mathrm{R} \%)$ were calculated based on the isotopic results (atoms \%), according to Trivelin [29].

\section{RESULTS AND DISCUSSION}

\subsection{The Mineralization of $\mathrm{N}$ from Legume Plants Incorporated into the Tow Soils with Contrasting Textural Classes and the Recovery of Nitrogen in Corn}

Nutrient contents in the plant material used are presented in Table 3 . Velvet bean showed a higher content of $\mathrm{N}$ for both the above-ground parts $\left(27 \mathrm{~g} \cdot \mathrm{dm}^{-3}\right)$ and the roots $\left(28 \mathrm{~g} \cdot \mathrm{dm}^{-3}\right)$, and the highest yield of dry mass for both the above-ground parts and the roots, resulting in a lower ${ }^{15} \mathrm{~N}$ labelling [20]. The bean residue had the lowest $\mathrm{N}$ concentration $\left(8 \mathrm{~g} \cdot \mathrm{dm}^{-3}\right)$ because it was the trash left over after grain harvesting. Slight differences were found among of the green manures nutrient contents and $\mathrm{C} / \mathrm{N}$ ratio, except for $\mathrm{P}$, with significant lower concentrations in the bean residue and in the sunn hemp, and for $\mathrm{Mn}$, with significant higher contents in the velvet bean. The bean residue also had the lowest micronutrient contents. Values observed are in agreement with those obtained by [30] for green manures produced in the field.

After seven days of incubation, the total amounts inorganic-N (NT) produced with the green manures and the control treatment were similar (Table 4). These results suggest that during this period there was no net immobilization of inorganic- $\mathrm{N}$, since the amounts of $\mathrm{N}$ mineralized from the plant material predominated over that of the native soil $\mathrm{N}$. However, this was not true for the bean residue treatment, which had a higher $\mathrm{C} / \mathrm{N}$ ratio (45), 
Table 3. Concentration of macro and micronutrients contents, and $\mathrm{C} / \mathrm{N}$ ratio for the above-ground parts (AP) and roots (R) of velvet bean, sunn hemp and bean residue.

\begin{tabular}{|c|c|c|c|c|c|c|c|c|c|c|c|}
\hline \multirow{2}{*}{ Leguminous } & $\mathrm{N}$ & $\mathrm{P}$ & $\mathrm{K}$ & $\mathrm{Ca}$ & $\mathrm{Mg}$ & $\mathrm{Fe}$ & $\mathrm{Mn}$ & $\mathrm{Zn}$ & $\mathrm{Cu}$ & $\mathrm{B}$ & $\mathrm{C} / \mathrm{N}$ \\
\hline & \multicolumn{4}{|c|}{$\mathrm{g} \cdot \mathrm{dm}^{-3}$} & \multicolumn{7}{|c|}{$\mathrm{mg} \cdot \mathrm{dm}^{-3}$} \\
\hline Velvet bean (AP) & 27 & 31 & 102 & 158 & 30 & 297 & 1133 & 66 & 9 & 50 & 15 \\
\hline Velvet bean (R) & 28 & 32 & 92 & 61 & 53 & 6285 & 1042 & 124 & 19 & 37 & 12 \\
\hline Sunn hemp (AP) & 16 & 18 & 71 & 80 & 35 & 111 & 280 & 31 & 5 & 37 & 25 \\
\hline Sunn hemp (R) & 12 & 16 & 41 & 41 & 20 & 6078 & 339 & 45 & 10 & 41 & 25 \\
\hline Common bean residue & 8 & 4 & 141 & 47 & 34 & 97 & 17 & 11 & 2 & 21 & 45 \\
\hline
\end{tabular}

Adapted from [19].

Table 4. Total mineralized $\left(\mathrm{NH}^{4} \mathrm{~N}\right.$ and $\mathrm{NO}^{3-} \mathrm{N}$ ) nitrogen (NT), derived from the green manure (NDGM) and derived from the soil (NS), for treatments with legumes and control, after 49 days of incubation. Means were calculated for two soils.

\begin{tabular}{|c|c|c|c|c|c|c|c|c|c|c|}
\hline \multirow{2}{*}{$\begin{array}{c}\text { Incubation } \\
\text { Period }\end{array}$} & \multicolumn{3}{|c|}{ Sunn hemp } & \multicolumn{3}{|c|}{ Velvet bean } & \multicolumn{3}{|c|}{ Bean residue } & \multirow{2}{*}{$\begin{array}{l}\text { Control } \\
\mathrm{NT}=\mathrm{NS}\end{array}$} \\
\hline & NT & NDGM & NS & NT & NDGM & NS & NT & NDGM & NS & \\
\hline Days & \multicolumn{10}{|c|}{$\mathrm{mg} \cdot \mathrm{N} \cdot \mathrm{kg}^{-1}$} \\
\hline 7 & $51 \mathrm{a}$ & $17 \mathrm{~A}$ & 34 & $53 a$ & $22 \mathrm{~A}$ & 31 & $6 c$ & 1B & 5 & $47 a$ \\
\hline 14 & $49 b$ & $16 \mathrm{~B}$ & 33 & $63 a$ & $27 \mathrm{~A}$ & 36 & $14 \mathrm{c}$ & $3 \mathrm{C}$ & 11 & $44 b$ \\
\hline 21 & $55 \mathrm{~b}$ & $18 \mathrm{~B}$ & 37 & $73 a$ & $38 \mathrm{~A}$ & 35 & $12 \mathrm{c}$ & $3 \mathrm{C}$ & 9 & $44 b$ \\
\hline 28 & $53 \mathrm{~b}$ & 17B & 36 & $77 \mathrm{a}$ & $40 \mathrm{~A}$ & 37 & $17 \mathrm{c}$ & $5 \mathrm{C}$ & 12 & $47 b$ \\
\hline 35 & $45 \mathrm{~b}$ & 17B & 28 & $63 a$ & $36 \mathrm{~A}$ & 27 & $21 \mathrm{c}$ & $6 \mathrm{C}$ & 15 & $50 \mathrm{~b}$ \\
\hline 42 & $41 \mathrm{~b}$ & 17B & 24 & $56 a$ & $28 \mathrm{~A}$ & 28 & $22 \mathrm{c}$ & $6 \mathrm{C}$ & 16 & $41 b$ \\
\hline 49 & $51 \mathrm{~b}$ & $23 \mathrm{~B}$ & 28 & $67 a$ & $37 \mathrm{~A}$ & 30 & $32 \mathrm{c}$ & $9 \mathrm{C}$ & 23 & $52 \mathrm{~b}$ \\
\hline
\end{tabular}

Means in the rows followed by different letters are significantly different according to the Tukey test at 5\%; lower case letters compare NT means, and capital letters are for inorganic-N NDGM. C.V. 21.9\% (NT) and 8.2\% (NDGM); Adapted from [19].

indicating that immobilization continued over the whole incubation period. Velvet bean showed significant higher contents of total inorganic-N (NT) than sunn hemp after 14 days of incubation.

In a general way, the amount of plant material added to the soil, as well as the amount of $\mathrm{N}$ added by the green manures, generated enough inorganic $\mathrm{N}$ so mineralization predominated over immobilization.

The $\mathrm{N}$ mineralized from the soil stock (NS) was lower for the treatments with green manures than for the control treatment $(\mathrm{NT}=\mathrm{NS})$. Similar results were obtained by [31], who observed a higher degree of mineralization of $\mathrm{N}$ from the plant material added, preventing the microbial mineralization of the $\mathrm{N}$ from the original organic matter. On the other hand, our results disagree with those of other experiments in which the addition of inorganic $\mathrm{N}$ caused an "apparent" higher mineralization of the soil organic matter [32] a phenomenon known as "Priming effect" [33], and currently called ANI, "Added Nitrogen Interaction" [34-36].

Table 5 shows the results on soil-N derived from the plant material. F-test results for linear effects are presented, since quadratic effect was found not to be significant. The above-ground part of velvet bean resulted in higher concentration of soil inorganic $\mathrm{N}$ during the whole incubation period compared with the other green manures. Velvet bean and sunn hemp initially had a similar $\mathrm{N}$ mineralization rate, but afterwards $\mathrm{N}$ mineralization from velvet bean showed was higher and occurred for a longer time. Inorganic $\mathrm{N}$ supply can be considered to be steady, since there were no plants to take up that nutrient. Other researchers, when comparing highly soluble and readily available inorganic $\mathrm{N}$ sources, found the maintenance of a steady mineralization to be a determinant aspect in the differentiation of the green manure $\mathrm{N}$ $[32,37]$.

All the treatments contributed steadily to provide inorganic-N to the soil, except velvet bean (AP) and bean residue, which gradually increased inorganic $\mathrm{N}$ contents along the incubation period (Table 6). For the bean residue, immobilization was found to be more intense in the first weeks after incubation, lately releasing the nitrogen. The bean residue had a higher $\mathrm{C} / \mathrm{N}$ ratio (45), resulting in the immobilization of the inorganic $\mathrm{N}$.

Results suggest that an incubation period of 49 days is recommended before growing a crop following common bean trash incorporation because of slow mineralization of organic $\mathrm{N}$. 
Table 5. Amounts of inorganic N-mineralized during a 49 day incubation period, derived from either the above-ground part N (NAP) or the roots $(\mathrm{NR})$ of ${ }^{15} \mathrm{~N}$ labeled green manures and bean residue, Mean values for two soils.

\begin{tabular}{|c|c|c|c|c|c|c|c|c|c|c|}
\hline \multirow{3}{*}{$\begin{array}{c}\text { Incubation } \\
\text { Period } \\
\text { Days }\end{array}$} & \multicolumn{4}{|c|}{ Sunn hemp } & \multicolumn{4}{|c|}{ Velvet bean } & \multirow{2}{*}{\multicolumn{2}{|c|}{$\frac{\text { Bean }}{\text { Residue }}$}} \\
\hline & \multicolumn{2}{|c|}{ NAP } & \multicolumn{2}{|c|}{ NR } & \multicolumn{2}{|c|}{ NAP } & \multicolumn{2}{|c|}{ NR } & & \\
\hline & $\%$ & $\mathrm{mg} \cdot \mathrm{kg}^{-1}$ & $\%$ & $\mathrm{mg} \cdot \mathrm{kg}^{-1}$ & $\%$ & $\mathrm{mg} \cdot \mathrm{kg}^{-1}$ & $\%$ & $\mathrm{mg} \cdot \mathrm{kg}^{-1}$ & $\%$ & $\mathrm{mg} \cdot \mathrm{kg}^{-1}$ \\
\hline 7 & $33.8 \mathrm{a}$ & $15.8 \mathrm{a}$ & $2.5 \mathrm{c}$ & $1.5 \mathrm{~b}$ & $38.0 \mathrm{a}$ & $18.3 \mathrm{a}$ & $6.0 \mathrm{c}$ & $3.5 \mathrm{~b}$ & $17.8 \mathrm{~b}$ & $1.1 \mathrm{~b}$ \\
\hline 14 & $34.7 \mathrm{a}$ & $14.9 \mathrm{~b}$ & $2.5 \mathrm{~d}$ & $1.4 \mathrm{~d}$ & $38.9 \mathrm{a}$ & $23.8 \mathrm{a}$ & $5.5 \mathrm{c}$ & $3.5 \mathrm{~cd}$ & $18.3 b$ & $2.8 \mathrm{c}$ \\
\hline 21 & $37.0 \mathrm{~b}$ & $16.6 \mathrm{~b}$ & $2.7 \mathrm{e}$ & $1.8 \mathrm{c}$ & $43.9 \mathrm{a}$ & $32.4 \mathrm{a}$ & $7.0 \mathrm{~d}$ & $5.2 \mathrm{c}$ & $24.1 \mathrm{c}$ & $3.3 \mathrm{c}$ \\
\hline 28 & $37.2 \mathrm{~b}$ & $15.1 \mathrm{~b}$ & $2.8 \mathrm{e}$ & $1.9 \mathrm{c}$ & $45.2 \mathrm{a}$ & $34.4 \mathrm{a}$ & $6.5 \mathrm{~d}$ & $5.1 \mathrm{c}$ & $26.1 \mathrm{c}$ & $4.7 \mathrm{c}$ \\
\hline 35 & $36.4 \mathrm{~b}$ & $15.3 \mathrm{~b}$ & $2.8 \mathrm{e}$ & $1.4 \mathrm{c}$ & $44.5 \mathrm{a}$ & $32.4 \mathrm{a}$ & $6.2 \mathrm{~d}$ & $3.4 \mathrm{c}$ & $26.1 \mathrm{c}$ & $5.7 \mathrm{c}$ \\
\hline 42 & $37.5 \mathrm{a}$ & $16.0 \mathrm{~b}$ & $3.0 \mathrm{~d}$ & $1.3 \mathrm{~d}$ & $41.8 \mathrm{a}$ & $23.1 \mathrm{a}$ & $7.8 \mathrm{c}$ & $4.4 \mathrm{~cd}$ & $27.2 \mathrm{~b}$ & $6.2 \mathrm{c}$ \\
\hline 49 & $38.1 \mathrm{~b}$ & $21.5 \mathrm{~b}$ & $3.1 \mathrm{e}$ & $1.4 \mathrm{~d}$ & $46.5 \mathrm{a}$ & $32.0 \mathrm{a}$ & $6.7 \mathrm{~d}$ & $4.6 \mathrm{~cd}$ & $26.7 \mathrm{c}$ & $8.7 \mathrm{c}$ \\
\hline $\mathrm{Fl}(1)$ & $\mathrm{ns}$ & $\mathrm{ns}$ & * & $\mathrm{ns}$ & * & * & $\mathrm{ns}$ & $\mathrm{ns}$ & $\mathrm{ns}$ & * \\
\hline R2 & - & - & 0.28 & - & 0.30 & 0.16 & - & - & - & 0.35 \\
\hline
\end{tabular}

Means followed by different lower case letters in the same column are significantly different (Tukey P $<0.05)$. (1) F-test, linear effect. C.V. $=8.2 \%$. Adapted from [19].

Table 6. Amount of total mineralized $\left(\mathrm{NH}^{4} \mathrm{~N}\right.$ and $\left.\mathrm{NO}^{3} \mathrm{~N}\right)$ nitrogen $(\mathrm{NT})$, and percentage of mineralized $\mathrm{N}$ derived from the above-ground part (AP) and roots (R) of ${ }^{15} \mathrm{~N}$ labeled green manures, and bean residue (NDGM), in both soils (Eutrudox and Paleudalf). Mean values after a 49 day incubation.

\begin{tabular}{ccccc}
\hline & \multicolumn{3}{c}{ NT } & \multicolumn{2}{c}{ NDGM } \\
\cline { 2 - 5 } Treatments & Eutrudox & Paleudalf & Eutrudox & Paleudalf \\
\cline { 2 - 5 } & \multicolumn{2}{c}{$\mathrm{mg} \cdot \mathrm{N}^{\prime} \cdot \mathrm{kg}^{-1}$} \\
Sunnhemp-AP & $38.1 \mathrm{~b} \mathrm{C}$ & $50.7 \mathrm{a} \mathrm{C}$ & $31.2 \mathrm{~b} \mathrm{~B}$ & $41.7 \mathrm{a} \mathrm{B}$ \\
Sunnhemp-R & $49.0 \mathrm{~b} \mathrm{~B}$ & $62.2 \mathrm{a} \mathrm{B}$ & $2.5 \mathrm{a} \mathrm{E}$ & $3.0 \mathrm{a} \mathrm{E}$ \\
Velvet bean-AP & $56.3 \mathrm{~b} \mathrm{~A}$ & $72.2 \mathrm{a} \mathrm{A}$ & $37.2 \mathrm{~b} \mathrm{~A}$ & $48.2 \mathrm{a} \mathrm{A}$ \\
Velvet bean-R & $59.0 \mathrm{~b} \mathrm{~A}$ & $71.8 \mathrm{a} \mathrm{A}$ & $6.0 \mathrm{a} \mathrm{D}$ & $7.0 \mathrm{a} \mathrm{D}$ \\
Bean residue & $21.7 \mathrm{a} \mathrm{D}$ & $21.7 \mathrm{a} \mathrm{D}$ & $18.7 \mathrm{~b} \mathrm{C}$ & $28.9 \mathrm{a} \mathrm{C}$ \\
\hline
\end{tabular}

Means followed by different letters are significantly different (Tukey $\mathrm{P}<0.05$ ); capital letters in the columns treatments and lower case letters on the rows soils. C.V. $=21.9 \%$ (NT) $-8.2 \%$ (NDGM); Adapted from [19].

Means of total inorganic $\mathrm{N}$ for both soils are presented in Table 6. The highest mineralization rate occurred in the Paleudalf soil. However, the bean residue showed similar values for both soils. The Paleudalf soil also showed the highest concentrations of $\mathrm{N}$ derived from the plant material, except for roots, that contributed similarly in both soils. Velvet bean was the treatment that mostly contributed to the inorganic $\mathrm{N}$ contents of both soils, followed by sunn hemp, bean residue, and legume roots.

The Eutrudox has a higher clay content which has a protective action on organic matter mating it less available for the activity of microorganisms. The soil analysis showed a higher organic matter content in the Eutrudox $\left(30 \mathrm{~g} \cdot \mathrm{dm}^{-3}\right)$ than in the Paleudalf $\left(10 \mathrm{~g} \cdot \mathrm{dm}^{-3}\right)$. According to [38], more than $90 \%$ of the $\mathrm{N}$ in the topsoils of most soils is in the organic form [39] also found, for a soil with low $\mathrm{N}$ content, a higher mineralization rate. In that case, about $13 \%$ of the inorganic $\mathrm{N}$ derived from the plant residue added, contrasting with the $5 \%$ found in a
N-richer soil. Jans-Hammermeister et al. [31] studied N mineralization rates in two soils amended with peas, and observed a higher rate associated with soils with low clay contents.

The soils where green manure was incorporated had higher $\mathrm{N}$ concentrations than those without incorporation. Regardless of soil type, whenever velvet bean was the incorporated source, $\mathrm{N}$ levels were higher (Table 7), as this can be explained by the higher $\mathrm{N}$ levels in velvet bean compared with sunn hemp (Table 3). Higher $\mathrm{N}$ accumulation in velvet bean can be explained by its largest N2 symbiotic fixation under the conditions of this study.

Differences were found between the mean total $\mathrm{N}$ concentrations of the two soils studied with Eutrudox having $1.259 \mathrm{mg} \cdot \mathrm{kg}^{-1}$ and Paleudalf $389 \mathrm{mg} \cdot \mathrm{kg}^{-1}$, regardless of treatment, incorporation or not of the green manures, legume plant part, or sampling time. That was due, largely, to the textural differences between the two 
Table 7. Total N concentrations in Eutrudox and Paleudalf soils in the different treatments.

\begin{tabular}{cccc}
\hline \multirow{2}{*}{ Soils } & Velvet bean & Sunn hemp & $\begin{array}{c}\text { Without green } \\
\text { manure }\end{array}$ \\
\cline { 2 - 4 } & \multicolumn{3}{c}{$\mathrm{mg} \cdot \mathrm{kg}^{-1}$} \\
\hline Eutrudox & $1315 \mathrm{a}$ & $1245 \mathrm{~b}$ & $1135 \mathrm{c}$ \\
Paleudalf & $435 \mathrm{a}$ & $363 \mathrm{~b}$ & $267 \mathrm{c}$ \\
$\mathrm{CV}=7.7 \%$ & & & \\
\hline
\end{tabular}

Means followed by the same letter, in the rows, are not different by Tukey test $(\mathrm{P}>0.05)$; Adapted from [14].

soils, the Eutrudox being heavier (higher percentage of clay), which slows organic matter decay [40-42]. This is corroborated by the higher levels of organic matter (OM) in the Eutrudox, $30 \mathrm{~g} \cdot \mathrm{dm}^{-3}$ of $\mathrm{OM}$ versus $10 \mathrm{~g} \cdot \mathrm{dm}^{-3}$ in the Paleudalf.

As observed in Figure 1, differences occurred between the total soil $\mathrm{N}$ amount and concentration that came from the green fertilizer aerial part over time. The aerial part contribution was on average $16.3 \%$ compared with $3.5 \%$ from roots, indicating that the aerial part participation was four times greater larger than that of the roots, reflecting the greater amount added from the aerial part. Over time the variable described a quadratic curve with the largest contribution at $20 \mathrm{DAE}$ decreasing afterwards to $60 \mathrm{DAE}$ and rising again $100 \mathrm{DAE}$ again, the same was not verified in roots.

These results are due, largely, to the uptake of the $\mathrm{N}$ that was incorporated by the corn from the green manure where the data described a quadratic curve, but contrary to what was described in Figure 1, with the highest $\mathrm{N}$ uptake at 60 DAE sampling and a decrease from that point to 100 DAE. Observed too the constant releasing nitrogen from the roots.

In Table 8 the mean data of $\%$ NSDGM are observed as a function of sampling time and of the legume plant part that was incorporated, for Eutrudox and Paleudalf soils. The contribution of the legume nitrogen in the Paleudalf soil, with the $\mathrm{N}$ supply from the velvet bean being was higher.

Four velvet bean, out of the $35 \%$, the aerial part contributes with $27.8 \%$ and the roots only $7.2 \%$ in the Paleudalf soil, higher than that in Eutrudox where the contribution of the aerial part that was $11.0 \%$ and $2.8 \%$ respectively for aerial part and roots. For sunn hemp the values were lower in the two soils. These results are consistent with the higher mineralization rate of the organic matter in soils with less clay, as observed above. The lower $\mathrm{C} / \mathrm{N}$ ratio in velvet bean aerial part as well as in roots is lower than in sunn hemp (Table 3) favoring its higher mineralization in both soils (Table 8).

The levels of mineral $\mathrm{N}$ (nitrate and ammonium) in the soil were higher until 40 DAE in the Velvet bean treatment followed by the sunn hemp and finally the check
(Table 9). It can be observed that beyond 60 DAE the values were low, smaller than $1.6 \mathrm{mg} \cdot \mathrm{kg}^{-1}$, without differences among treatments (Table 9).

For the sunn hemp, there were differences among the times, with a decline in the green manure contribution to the soil mineral N. However, this did not happen with the velvet bean treatment indicating that, besides the largest contribution of the green manure plants to the soil mineral $\mathrm{N}$, there was also greater mineralization, since the test-plant (corn) kept on taking up mineral $\mathrm{N}$ from the soil.

It is observed in the Table $\mathbf{1 0}$ that the Paleudalf had higher mineral $\mathrm{N}$ concentration than the Eutrudox soil regardless of the soil sampling time. These results are in agreement with those obtained by [39] who found higher organic matter mineralization in low-N soils. In that study, the authors observed that $13 \%$ of the mineral nitrogen originated from the added plant residue, compared to $5 \%$ in the high-N soil. Jans-Hammermeister et al. [31] observed $\mathrm{N}$ mineralization rates in two soils after addition of pea aerial part and verified that the higher rates were associated with soils that had lower clay percentages. Similar results were also verified by [43] and other authors cited by [44].

With regard to the accumulated nitrogen in the corn aerial part $\left(\mathrm{mg} \cdot\right.$ pot $\left.^{-1}\right)$ it can be observed from Table 11 that there was a quadratic response with increments $u p$ until 60 DAE followed by a decrease. It can be emphasized that up to $30 \mathrm{DAE}$ corn plant growth did not show differences among treatments, due to the low plant growth and nitrogen uptake, but starting at $40 \mathrm{DAE}$ there was greater $\mathrm{N}$ accumulation in plants under the green manure treatments, showing that from that stage onwards plants started to take up more nitrogen and those treatments revealed conditions of supplying it. Starting at 60 DAE it can be highlighted that the crotalaria treatment plants accumulated more nitrogen than those under the Velvet bean treatment.

The decline in accumulated nitrogen in the corn plant aerial part, at the end of the (Table 11), was also reported by other authors $[45,46]$, as well as in sugarcane [47]. It has been offered as explanation the fact that that some $\mathrm{N}$ of the aerial part can be redistributed to the root system,

Table 8. Nitrogen percentage of the Eutrudox and Paleudalf soils originating from the green manure (\% NSDGM).

\begin{tabular}{ccc}
\hline \multirow{2}{*}{ Soils } & Velvet bean & Sunn hemp \\
\cline { 2 - 3 } & \multicolumn{2}{c}{$\operatorname{NSDGM(\% )}$} \\
\hline Paleudalf & $35.0 \mathrm{a} \mathrm{A}$ & $22.0 \mathrm{a} \mathrm{B}$ \\
Eutrudox & $13.8 \mathrm{~b} \mathrm{~A}$ & $8.6 \mathrm{~b} \mathrm{~B}$ \\
$\mathrm{CV}=8.7 \%$ & & \\
\hline
\end{tabular}

Means followed by the same lower case letter, in the rows, and capital letter in the column, are not different by Tukey test $(\mathrm{P}<0.05)$; Adapted from [14]. 


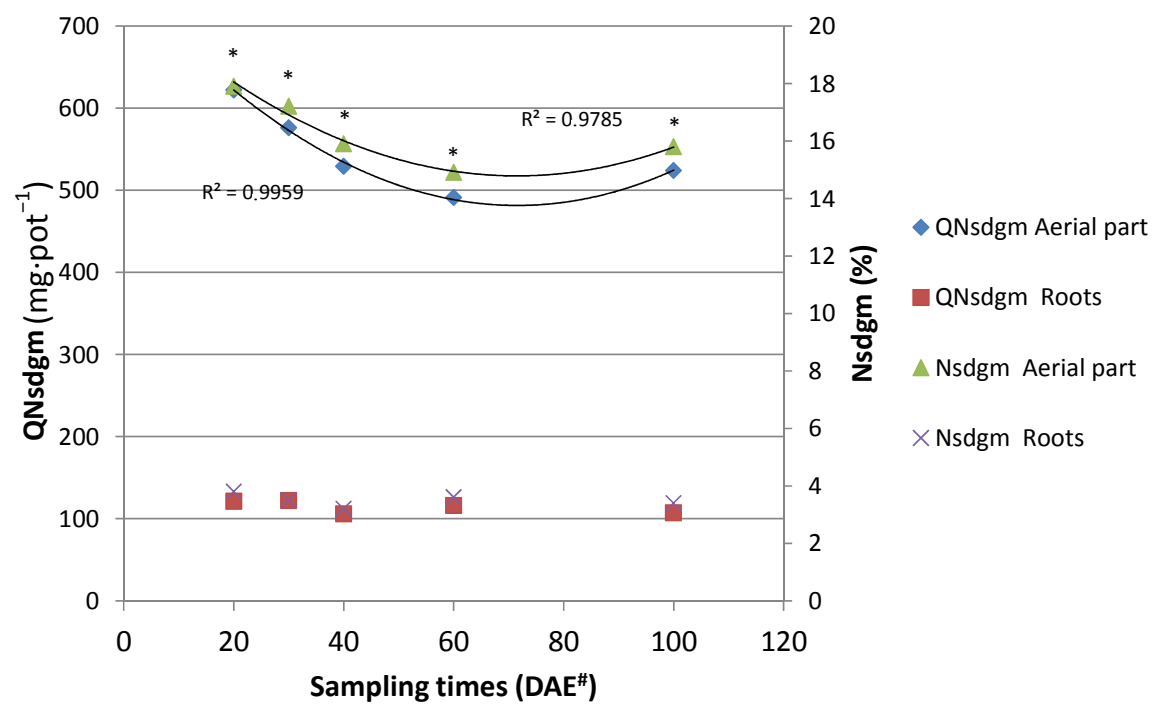

Figure 1. Amount of total soil nitrogen (mean of the two soils) from different parts of the green manure labelled with ${ }^{15} \mathrm{~N}\left(\mathrm{QNsdgm}, \mathrm{mg} \cdot \operatorname{pot}^{-1}\right)$ and percentage of total soil $\mathrm{N}$ from different parts of the green manure labelled with ${ }^{15} \mathrm{~N}$ (Nsdgm, \%) at the sampling times. There was no significant difference $(\mathrm{P}>0.05)$ between the sample times for QNsdgm Roots and Nsdgm Roots. ${ }^{*}$ The aerial part presented a greater amount of nitrogen than the roots for every sampling time. "Days after emergence of corn. Adapted from [14].

Table 9. $\mathrm{N}-\mathrm{NH}^{4+}+\mathrm{N}-\mathrm{NO}^{2-}+\mathrm{N}-\mathrm{NO}^{3-}$ concentrations over time.

\begin{tabular}{|c|c|c|c|}
\hline Sampling times & Velvet bean & Sunn hemp & Without green manure \\
\hline $\mathrm{DAE}^{+}$ & \multicolumn{3}{|c|}{$\left(\mathrm{N}-\mathrm{NH}^{4+}+\mathrm{N}-\mathrm{NO}^{2-}+\mathrm{N}^{-\mathrm{NO}^{3-}}\right) \mathrm{mg} \mathrm{N} \mathrm{kg}^{-1}$} \\
\hline 20 & $25.0 \mathrm{a}$ & $16.5 \mathrm{~b}$ & $10.1 \mathrm{c}$ \\
\hline 30 & $19.6 \mathrm{a}$ & $8.4 \mathrm{~b}$ & $4.3 \mathrm{c}$ \\
\hline 40 & $14.5 \mathrm{a}$ & $2.3 \mathrm{~b}$ & $0.7 \mathrm{~b}$ \\
\hline 60 & $1.6 \mathrm{a}$ & $0.8 \mathrm{a}$ & $0.4 \mathrm{a}$ \\
\hline 100 & $0.7 \mathrm{a}$ & $0.6 \mathrm{a}$ & $0.4 \mathrm{a}$ \\
\hline F linear & * & * & * \\
\hline F quadrático & * & * & * \\
\hline $\mathrm{R} 2$ & 0.76 & 0.78 & 0.69 \\
\hline $\mathrm{CV}=34.5 \%$ & & & \\
\hline
\end{tabular}

Means followed by the same lower case letter, in the rows, are not different by Tukey test $(\mathrm{P}>0.05)$. Adapted from [14]. ${ }^{+} \mathrm{DAE}$ : Days after emergence of corn. "Significant at $(\mathrm{P}<0.05)$.

Table 10. $\mathrm{N}-\mathrm{NH}^{4+}+\mathrm{N}-\mathrm{NO}^{2-}+\mathrm{N}-\mathrm{NO}^{3-}$ levels in Eutrudox and Paleudalf soils.

\begin{tabular}{ccc}
\hline & Soil Eutrudox & Soil Paleudalf \\
\cline { 2 - 3 } Treatments & & $\mathrm{mg} \cdot \mathrm{N} \cdot \mathrm{kg}^{-1}$ \\
\hline Velvet bean & $10.0 \mathrm{~b}$ & $14.6 \mathrm{a}$ \\
Sunn hemp & $4.5 \mathrm{~b}$ & $6.9 \mathrm{a}$ \\
Without green manure & $3.3 \mathrm{a}$ & $3.3 \mathrm{a}$ \\
$\mathrm{CV}=34.5 \%$ & & \\
\hline
\end{tabular}

Means followed by the same lower case letter, in the rows, are not different by Tukey test $(\mathrm{P}>0.05)$. Adapted from [14]. 
Table 11. Accumulated $\left(\mathrm{mg} \cdot \operatorname{pot}^{-1}\right)$ nitrogen in the corn aerial part with and without green manure, as a function of time.

\begin{tabular}{cccc}
\hline Sampling times & Velvet bean & Sunn hemp & Without green manure \\
\hline DAE + & & mg $\cdot$ pot $^{-1}$ & $205 \mathrm{a}$ \\
\hline 20 & $194 \mathrm{a}$ & $187 \mathrm{a}$ & $340 \mathrm{a}$ \\
30 & $340 \mathrm{a}$ & $326 \mathrm{a}$ & $322 \mathrm{~b}$ \\
40 & $433 \mathrm{a}$ & $427 \mathrm{a}$ & $428 \mathrm{c}$ \\
60 & $546 \mathrm{~b}$ & $819 \mathrm{a}$ & $322 \mathrm{c}$ \\
100 & $423 \mathrm{~b}$ & $573 \mathrm{a}$ & $*$ \\
F linear & $*$ & $*$ & $*$ \\
F quadratic & $*$ & 0.74 & 0.64 \\
R2 & 0.81 & &
\end{tabular}

Means followed by the same lower case letter, in the rows, are not different by Tukey test $(\mathrm{P}>0.05)$. Adapted from [14]. $+\mathrm{DAE}$ : Days after emergence of corn. *Significant at $(\mathrm{P}<0.05)$.

as well as lost to the atmosphere by volatilization through the leaves via transpiratory strem either imamture or senescing leaves. According to [48], $\mathrm{NH}_{3}$ gaseous losses happen through the leaves due to the increase in proteolysis during senescence.

It can be noticed that the percentage of plant nitrogen from the green manure was practically constant during the experiment (Table 12). This fact is not usually observed when mineral fertilizer or another soluble $\mathrm{N}$ source is applied, where a greater proportion of the nitrogen use from the fertilizer happens initially with a reduction in these values in subsequent stages [32,37,47]. The amounts of $\mathrm{N}$ in the aerial part of the corn plant that was derived from the green fertilizer, for the two legume species, as a function of time can be observed in Table 12. No differences among treatments were observed until 40 DAE, however at 60 DAE the Velvet bean turned out to be the major $\mathrm{N}$ supplier to the corn plant, probably due to the largest $\mathrm{N}$ concentration in that green manure, and its lower $\mathrm{C} / \mathrm{N}$ ratio (Table 3 ).

Despite the higher amounts of $\mathrm{N}$ accumulated in the sunn hemp treatments, at the 60 and 100 DAE sampling dates (Table 11) the amount of $\mathrm{N}$ from the green manures was higher for the black-mucuna, at any given same date, indicating the al for $\mathrm{N}$ supply potential of this plant (Table 12).

The reduction in the amounts accumulated at the end of the cycle followed the same pattern verified for the total nitrogen and is likely due to the loss of nitrogenous compounds from mature or pre-senescence leaves, which can happen next to the transpiratory strem $[49,50]$.

The accumulation of $\mathrm{N}$ in corn roots increased with time. These results indicate that there are also losses due to shedding, root exudation and root death [51], losses of
$\mathrm{N}$ from the aerial part are much more expressive, and the aerial part $\mathrm{N}$ can be translocated to the roots reflecting on the accumulation of $\mathrm{N}$ in roots (Table 13).

There was an increase in dry matter mass of the corn aerial part up until 100 DAE. At that stage, the plants were beginning to flower. The only significant difference observed was at the first time (20 DAE), when the check plants produced more than those with green manure (Table 14).

The results suggest that, at that time there was no net immobilization of nitrogen, however, by adding corn as test plant, the initial productivity was harmed by the treatments with green manure as observed in Table 15. After that initial period corn productivity was similar to the control treatment.

Regarding the corn roots, there was an increase in dry mass with time, and as observed for the aerial part, treatment effects were not verified, beyond 20 DAE (Table 15).

With regard to $\mathrm{N}$ balance in the soil-plant system, it can be seen in Figure 2 that for the Eutrodux soil 80\% of the $\mathrm{N}$ added, by the legume roots, stayed in the soil and less than $20 \%$ went to the corn plant, indicating that the added material, that usually has a high $\mathrm{C} / \mathrm{N}$ ratio, stays longer in the soil.

In the Paleudalf soil it is observed that larger $\mathrm{N}$ amounts of the green manure went to the corn plants (more than 20\%), and a larger amount of $\mathrm{N}$ was lost from the system, indicating higher mineralization of nitrogen in that soil.

Studies developed with the addition of organic $\mathrm{N}$ to soils $[13,14,52,53]$ rarely exceed $20 \%$ in their use and indicate that the greatest proportion of $\mathrm{N}$ contained in its dry matter goes to the soil $[54,55]$. Thus, the use of green 
Table 12. Nitrogen percentage in the corn aerial part derived of the green fertilizer aerial part and roots in the time function.

\begin{tabular}{cccc}
\hline Sampling times & Aerial part & Roots & Total \\
\hline DAE $^{+}$ & & $\%$ & 45.0 \\
\hline 20 & $40.0 \mathrm{a}$ & $5.0 \mathrm{~b}$ & 47.3 \\
30 & $42.4 \mathrm{a}$ & $4.9 \mathrm{~b}$ & 46.6 \\
40 & $41.5 \mathrm{a}$ & $5.1 \mathrm{~b}$ & 47.4 \\
60 & $41.7 \mathrm{a}$ & $5.7 \mathrm{~b}$ & 46.5 \\
100 & $41.6 \mathrm{a}$ & $4.8 \mathrm{~b}$ & $\mathrm{~ns}$ \\
F linear & $\mathrm{ns}$ & $\mathrm{ns}$ & \\
F quadratic & $\mathrm{ns}$ & & \\
CV $=6.3 \%$ & & &
\end{tabular}

Means followed by the same lower case letter, in the rows, are not different by Tukey test $(\mathrm{P}>0.05)$. Adapted from [14]. ${ }^{+} \mathrm{DAE}$ : Days after emergence of corn. ns non significant.

Table 13. Amount of $\mathrm{N}$ accumulated in the aerial part of the corn plant derived from the green manure (QNpadgm) in treatments as a function of time.

\begin{tabular}{|c|c|c|}
\hline Sampling times & Sunn hemp & Velvet bean \\
\hline DAE & & \\
\hline 20 & $74 \mathrm{a}$ & $94 \mathrm{a}$ \\
\hline 30 & $138 \mathrm{a}$ & $166 \mathrm{a}$ \\
\hline 40 & $170 \mathrm{a}$ & $212 \mathrm{a}$ \\
\hline 60 & $212 b$ & $452 \mathrm{a}$ \\
\hline 100 & $160 \mathrm{~b}$ & $310 \mathrm{a}$ \\
\hline $\mathrm{F}$ linear & $\mathrm{ns}$ & * \\
\hline F quadratic & * & * \\
\hline $\mathrm{R} 2$ & 0.10 & 0.22 \\
\hline $\mathrm{CV}=28.7 \%$ & C.V. roots $=43.4 \%$ & \\
\hline
\end{tabular}

Means followed by the same lower case letter, in the rows, are not different by Tukey test $(\mathrm{P}>0.05)$. Adapted from [14]. $+\mathrm{DAE}$ : Days after emergence of corn. *Significant $(\mathrm{P}<0.05)$; ns non significant.

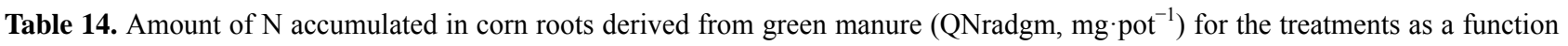
of time.

\begin{tabular}{cc}
\hline Sampling times & QNradgm \\
\hline DAE $^{+}$ & $\mathrm{mg} \cdot$ pot $^{-1}$ \\
\hline 20 & 16 \\
30 & 28 \\
40 & 26 \\
60 & 34 \\
100 & 50 \\
F linear & $*$ \\
F quadratic & $\mathrm{ns}$ \\
R2 & 0.14 \\
CV $=43.4$ & \\
\hline
\end{tabular}

\footnotetext{
${ }^{+}$DAE: Days after emergence of corn. Adapted from [14]. "Significant $(\mathrm{P}<0.05)$; ns: non significant.
} 
Table 15. Dry mass production of the corn aerial part and roots $\left(\mathrm{g} \cdot \operatorname{pot}^{-1}\right)$ with and without green manure treatments, as a function of sampling time.

\begin{tabular}{|c|c|c|c|c|c|c|}
\hline \multirow{3}{*}{ Sampling times } & \multicolumn{2}{|c|}{ Sunn hemp } & \multicolumn{2}{|c|}{ Velvet bean } & \multicolumn{2}{|c|}{ Without green manure } \\
\hline & Roots & Aerial part & Roots & Aerial part & Roots & Aerial part \\
\hline & \multicolumn{6}{|c|}{$g \cdot \operatorname{pot}^{-1}$} \\
\hline 20 & $2.0 \mathrm{a}$ & $4.9 \mathrm{a}$ & $1.9 \mathrm{a}$ & $4.5 \mathrm{a}$ & $2.2 \mathrm{~b}$ & $5.3 \mathrm{~b}$ \\
\hline 30 & $3.3 \mathrm{a}$ & $10.7 \mathrm{a}$ & $3.2 \mathrm{a}$ & $8.9 \mathrm{a}$ & $4.1 \mathrm{a}$ & $10.8 \mathrm{a}$ \\
\hline 40 & $6.0 \mathrm{a}$ & $17.6 \mathrm{a}$ & $3.4 \mathrm{a}$ & $13.7 \mathrm{a}$ & $5.3 \mathrm{a}$ & $14.3 \mathrm{a}$ \\
\hline 60 & $11.3 \mathrm{a}$ & $37.5 \mathrm{a}$ & $8.7 \mathrm{a}$ & $41.3 \mathrm{a}$ & $12.2 \mathrm{a}$ & $38.4 \mathrm{a}$ \\
\hline 100 & $19.5 \mathrm{a}$ & $61.8 \mathrm{a}$ & $18.5 \mathrm{a}$ & $62.9 \mathrm{a}$ & $13.8 \mathrm{a}$ & $55.4 \mathrm{a}$ \\
\hline $\mathrm{F}$ linear & * & * & $*$ & $*$ & $*$ & * \\
\hline F quadratic & * & * & $*$ & $*$ & * & * \\
\hline \multirow[t]{2}{*}{$\mathrm{R} 2$} & 0.86 & 0.97 & 0.79 & 0.92 & 0.84 & 0.95 \\
\hline & \multicolumn{6}{|c|}{ C.V.Aerial part $=8.5 \%$. C.V.Roots $=18.8 \%$} \\
\hline
\end{tabular}

Means followed by the same lower case letter, in the rows, are not different by Tukey test $(\mathrm{P}>0.05)$. Adapted from [14]. ${ }^{+} \mathrm{DAE}$ : Days after emergence of corn. "Significant $(\mathrm{P}<0.05)$; ns: non significant.

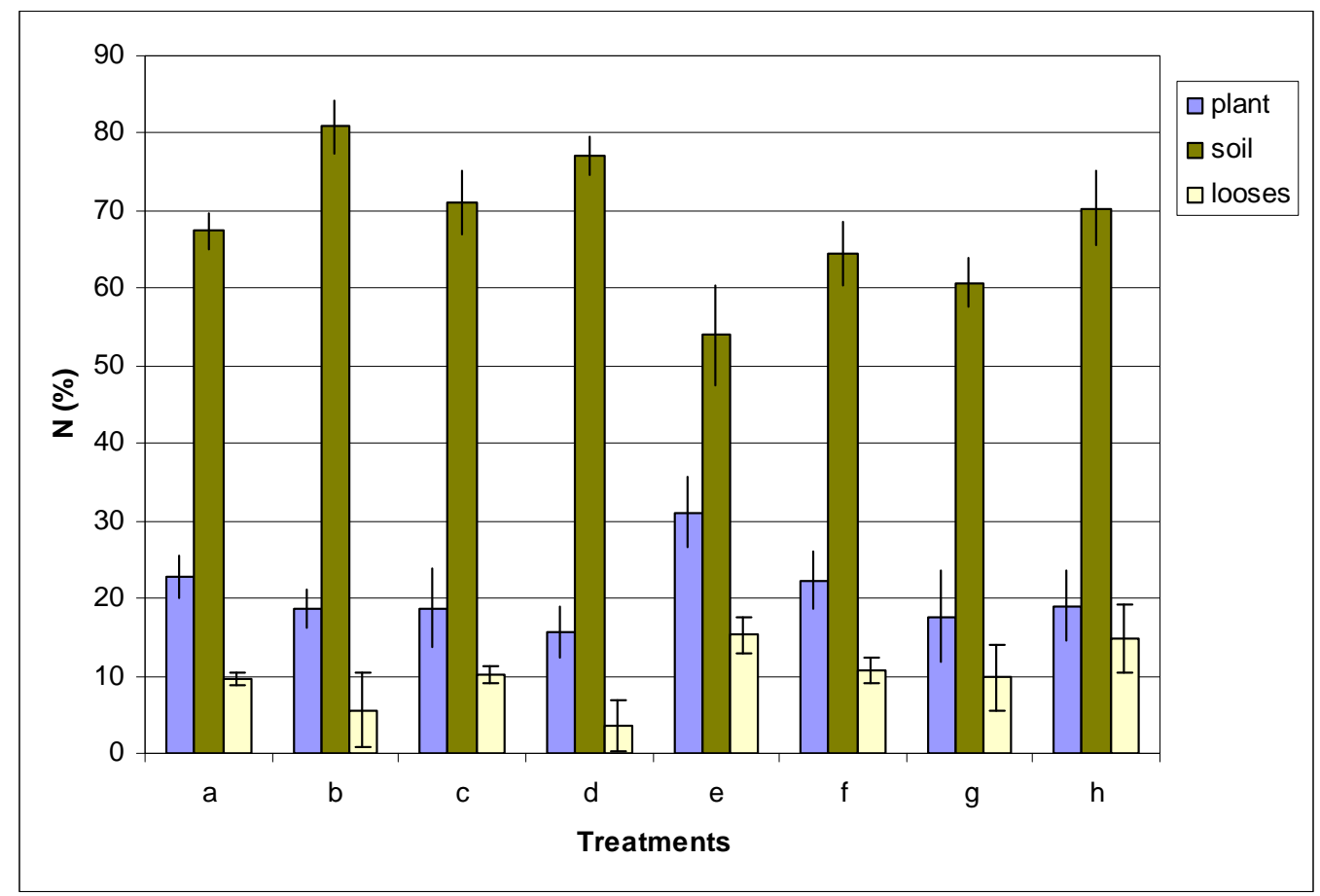

Figure 2. Nitrogen balance originating from green manuring in corn. a: Sunn hemp Eutrodux Aerial part; b: Sunn hemp Eutrodux Roots; c: Velvet bean Eutrodux Aerial part; d: Velvet bean Eutrodux Roots; e: Sunn hemp Paleudalf Aerial part; f: Sunn hemp Paleudalf Roots; g: Paleudalf Aerial part; h: Velvet bean Paleudalf Roots. Adapted from [14].

manures can be beneficial to the subsequent crop as well as to other crops in a rotation system due to its residual effect.

\subsection{To Evaluate the Utilization of Nitrogen by Sugarcane (Saccharum spp.) Fertilized with Sunn Hemp (SH) and Ammonium Sulfate (AS)}

The presence of a green manure crop and mineral $\mathrm{N}$ applied together caused some soil alterations that could be detected in samples collected in the sugarcane planting and harvesting seasons (Table 16). There was an increase in calcium and magnesium availability, and consequently in base saturation and $\mathrm{pH}$, in relation to the AS- ${ }^{15} \mathrm{~N}$ treatment, at planting. Similar results were obtained by [56], who worked with four velvet bean cultivars, velvet bean, Georgia velvet bean, cowitch, and cratylia. The presence of green manure caused a significant 
sum of bases increase, due to increases in calcium and magnesium; consequently, treatments involving velvet bean showed higher CEC values. The presence of organic acids in the plant mass could be the reason for this change.

During sugarcane harvest, increases in $\mathrm{Mg}$ concentration, $\mathrm{pH}$, and base saturation $(\mathrm{V} \%)$ were observed in the treatments containing $\mathrm{SH}_{-}{ }^{15} \mathrm{~N}+\mathrm{AS}$ in relation to the treatment containing $\mathrm{AS}^{-15} \mathrm{~N}$ alone. Also, a significant reduction in potential acidity was observed in treatments containing $\mathrm{SH}_{-}{ }^{15} \mathrm{~N}+\mathrm{AS}$ in relation to the treatment containing AS- ${ }^{15} \mathrm{~N}$ alone (Table 16).

The presence of organic acids in decomposing plant residues can help $\mathrm{Mg}$ movement in the soil [57]. Crops with high $\mathrm{C}: \mathrm{N}$ ratio may release $\mathrm{N}$ more slowly and cause an increase in $\mathrm{N}$ uptake by succeeding crop In addition, rotational plants that were grown before sugarcane could recycle nutrients that would otherwise be leached contribute with $\mathrm{N}$ derived from BNF and keep some elements in plant available forms, which could be transformed into more recalcitrant forms if the soil lie fallow for some time.

There was no variation in nutrient contents for macronutrients $\mathrm{N}$ and $\mathrm{P}$, and for micronutrients $\mathrm{B}$ and $\mathrm{Zn}$ in sugarcane stalks at harvest time (Table 17). However, there were differences in $\mathrm{Ca}$ and $\mathrm{K}$ contents; the latter showed higher values in treatments involving fertilizer application, either mineral or organic, while Ca showed a higher value in the treatment with green manure and mineral $\mathrm{N}$, indicating better nutrition with this element in the treatment containing higher nitrogen supply.

Nitrogen and potassium absorption is greatly influ- enced by moisture; this relation has been known for a long time [58], and the fact that treatments involving green manure crops maintained environments with higher moisture due to soil mulching with plant mass could have favored better potassium nutrition. With regard to calcium, nitrogen seems to favor absorption [59].

When sugarcane was cultivated for five years and was harvested three times. ${ }^{15} \mathrm{~N}$ recovery was evaluated in the two first harvests. In the sum of the three harvests, the highest stalk yields were obtained with a combination of green manure and inorganic $\mathrm{N}$ fertilizer; however, in the second cutting the yields were higher where sunn hemp (SH) was used than in plots with ammonium sulfate (AS) (Table 18).

Millable stalk yields of the first cycle (plant cane, harvested 18 months after planting) were higher than those of the second and the third cycle (Table 18). The yield decline with time is common, especially in the cases such as the present experiment when only the first cycle crop was fertilized in order to evaluate the residual effect of $\mathrm{N}$ application in the mineral or green manure forms. In the first year the stalk yield was numerically higher in plots fertilized with a combination of green manure and AS; however, in the second year the plots that received $\mathrm{SH}$ produced more cane than those fertilized only with AS or the control treatment, indicating that the green manure applied before planting still affected plant growth and yield after 34 months. In the third cycle, there were no differences among the treatments, showing that the residual effect of both $\mathrm{N}$ sources had disappeared (Table 18). In the sum of three cuttings, the combination of AS and green manure resulted in highest yields.

Table 16. Chemical characterization of the soil $(0-0.2 \mathrm{~m}$ depth $)$ in the sugarcane planting and harvesting seasons.

\begin{tabular}{|c|c|c|c|c|c|c|}
\hline \multirow{3}{*}{ Treatments } & \multicolumn{6}{|c|}{ Soil sampling at planting } \\
\hline & $\mathrm{pH}\left(\mathrm{CaCl}_{2}\right)$ & $\mathrm{Ca}$ & $\mathrm{Mg}$ & $\mathrm{H}+\mathrm{Al}$ & ${ }^{*} \mathrm{SB}$ & ${ }^{* *} \mathrm{BS}$ \\
\hline & $0.01 \mathrm{~mol} \cdot 1^{-1}$ & \multicolumn{4}{|c|}{$\mathrm{mmolc} \cdot \mathrm{dm}^{-3}$} & $\%$ \\
\hline Control & $5.1 \mathrm{ab}$ & $20.5 \mathrm{ab}$ & $14.5 \mathrm{ab}$ & $37.8 \mathrm{a}$ & $35.4 \mathrm{ab}$ & $48.2 \mathrm{a}$ \\
\hline $\mathrm{AS}-{ }^{15} \mathrm{~N}^{2}$ & $4.7 \mathrm{~b}$ & $15.8 \mathrm{~b}$ & $9.8 \mathrm{~b}$ & $47.0 \mathrm{a}$ & $25.9 \mathrm{~b}$ & $36.0 \mathrm{a}$ \\
\hline $\mathrm{SH}-{ }^{15} \mathrm{~N}$ & $5.0 \mathrm{ab}$ & $18.0 \mathrm{ab}$ & $13.0 \mathrm{ab}$ & $39.0 \mathrm{a}$ & $31.4 \mathrm{ab}$ & $44.5 \mathrm{a}$ \\
\hline \multirow[t]{2}{*}{ C.V.\% } & 5.12 & 7.55 & 10.76 & 20.77 & 6.81 & 22.52 \\
\hline & \multicolumn{6}{|c|}{ Soil sampling at harvest } \\
\hline Control & $5.0 \mathrm{ab}$ & $17.8 \mathrm{a}$ & $14.0 \mathrm{ab}$ & $39.8 \mathrm{ab}$ & $32.2 \mathrm{a}$ & $44.5 \mathrm{ab}$ \\
\hline $\mathrm{SH}+\mathrm{AS}^{-15} \mathrm{~N}$ & $5.6 \mathrm{a}$ & $24.7 \mathrm{a}$ & $26.8 \mathrm{a}$ & $25.5 \mathrm{~b}$ & $44.4 \mathrm{a}$ & $67.5 \mathrm{a}$ \\
\hline $\mathrm{SH}-{ }^{15} \mathrm{~N}$ & $5.0 \mathrm{ab}$ & $19.0 \mathrm{a}$ & $15.3 \mathrm{ab}$ & $36.3 \mathrm{ab}$ & $34.5 \mathrm{a}$ & $48.5 \mathrm{ab}$ \\
\hline C.V.\% & 8.00 & 30.88 & 15.18 & 25.87 & 32.45 & 29.57 \\
\hline
\end{tabular}

Means followed by different letters vertically in each sampling season are different by Tukey test $(\mathrm{P}<0.05) ;{ }^{2} \mathrm{AS}-{ }^{15} \mathrm{~N}\left({ }^{15} \mathrm{~N}-\mathrm{labeled}\right.$ ammonium sulfate), SH + AS- ${ }^{15} \mathrm{~N}$ (sunn hemp $+{ }^{15} \mathrm{~N}$-labeled ammonium sulfate), $\mathrm{SH}-{ }^{15} \mathrm{~N}\left({ }^{15} \mathrm{~N}\right.$-labeled sunn hemp). ${ }^{*} \mathrm{SB}=$ sum bases and ${ }^{* *} \mathrm{BS}=$ bases saturation. Adapted from [15]. 
Table 17. N, K, P, Ca, Zn, and B contents in sugarcane stalks at harvest time.

\begin{tabular}{|c|c|c|c|c|c|c|}
\hline \multirow{3}{*}{ Treatments } & $\mathrm{N}$ & K & $\mathrm{P}$ & $\mathrm{Ca}$ & $\mathrm{Zn}$ & B \\
\hline & \multicolumn{6}{|c|}{ Contents determined in sugarcane stalks at harvest } \\
\hline & \multicolumn{4}{|c|}{$\mathrm{g} \cdot \mathrm{kg}^{-1}$} & \multicolumn{2}{|c|}{$\mathrm{mg} \cdot \mathrm{kg}^{-1}$} \\
\hline Control & $7.2 \mathrm{a}$ & $3.3 \mathrm{~b}$ & $0.8 \mathrm{a}$ & $1.6 \mathrm{~b}$ & $10.9 \mathrm{a}$ & $12.1 \mathrm{a}$ \\
\hline AS $-{ }^{15} \mathrm{~N}^{2}$ & $8.1 \mathrm{a}$ & $6.7 \mathrm{a}$ & $0.9 \mathrm{a}$ & $1.7 \mathrm{~b}$ & $15.3 \mathrm{a}$ & $14.9 \mathrm{a}$ \\
\hline $\mathrm{SH}-{ }^{15} \mathrm{~N}$ & $7.7 \mathrm{a}$ & $7.1 \mathrm{a}$ & $0.9 \mathrm{a}$ & $1.8 \mathrm{~b}$ & $13.3 \mathrm{a}$ & $14.8 \mathrm{a}$ \\
\hline $\mathrm{SH}+\mathrm{AS}-{ }^{15} \mathrm{~N}$ & $8.8 \mathrm{a}$ & $8.5 \mathrm{a}$ & $1.0 \mathrm{a}$ & $2.4 \mathrm{a}$ & $13.7 \mathrm{a}$ & $15.4 \mathrm{a}$ \\
\hline C.V.\% & 11.52 & 27.89 & 15.61 & 8.14 & 19.80 & 18.00 \\
\hline
\end{tabular}

Means followed by different letters vertically in each sampling season are different by Tukey test $(\mathrm{P}<0.05) ;{ }^{2} \mathrm{AS}-{ }^{15} \mathrm{~N}\left({ }^{15} \mathrm{~N}-\mathrm{labeled}\right.$ ammonium sulfate), SH- ${ }^{15} \mathrm{~N}$ $\left({ }^{15} \mathrm{~N}\right.$-labeled sunn hemp), $\mathrm{SH}+\mathrm{AS}-{ }^{15} \mathrm{~N}$ (sunn hemp $+{ }^{15} \mathrm{~N}$-labeled ammonium sulfate) Adapted from [15].

Table 18. Millable stalk yield and $\mathrm{POL}^{1}$ of sugarcane plants in three consecutive harvests as a function of $\mathrm{N}$ applied at planting as ammonium sulfate (AS) or Sunn hemp (SH) green manure ${ }^{1}$.

\begin{tabular}{|c|c|c|c|c|c|}
\hline \multirow{2}{*}{ Treatments $^{2}$} & \multicolumn{3}{|c|}{ Harvests } & \multirow{2}{*}{ Total of three cuttings } & \multirow{2}{*}{ Mean $\pm \mathrm{SEM}^{3}$} \\
\hline & 24 Aug 2002 & 08 Oct 2003 & 20 Sep 2004 & & \\
\hline & \multicolumn{5}{|c|}{ Stalk yield, $\mathrm{Mg} \cdot \mathrm{ha}^{-1}$} \\
\hline Control & $86.0 \mathrm{Ba}$ & $61.1 \mathrm{Bab}$ & $47.1 \mathrm{Ab}$ & b194.2 & $64.7 \pm 4.6$ \\
\hline $\mathrm{AS}^{15} \mathrm{~N}$ & $106.2 \mathrm{ABa}$ & $64.7 \mathrm{Bb}$ & $42.3 \mathrm{Ab}$ & $\mathrm{ab} 213.2$ & $71.1 \pm 4.6$ \\
\hline $\mathrm{SH}+\mathrm{AS}^{15} \mathrm{~N}$ & $128.7 \mathrm{Aa}$ & $84.5 \mathrm{Ab}$ & $45.0 \mathrm{Ac}$ & a258.2 & $86.1 \pm 4.6$ \\
\hline $\mathrm{SH}^{15} \mathrm{~N}$ & $92.4 \mathrm{ABa}$ & 83.8 Aa & $41.2 \mathrm{Ab}$ & $a b 217.3$ & $72.4 \pm 4.6$ \\
\hline \multirow[t]{2}{*}{ Mean \pm SEM } & $103.3 \pm 3.8 \mathrm{a}$ & $73.5 \pm 3.8 b$ & $43.9 \pm 3.8 \mathrm{c}$ & $215.4 \pm 18.9$ & \\
\hline & \multicolumn{5}{|c|}{ POL, Mg $\cdot \mathrm{ha}^{-1}$} \\
\hline Control & 11.9 & 10.4 & 17.9 & $\mathrm{~b} 40.2$ & $13.5 \pm 0.7 \mathrm{~B}$ \\
\hline $\mathrm{AS}^{15} \mathrm{~N}$ & 14.9 & 11.1 & 17.5 & $a b 43.5$ & $14.5 \pm 0.6 \mathrm{AB}$ \\
\hline $\mathrm{SH}+\mathrm{AS}^{15} \mathrm{~N}$ & 17.0 & 14.1 & 18.4 & $\mathrm{a} 49.5$ & $16.5 \pm 0.6 \mathrm{~A}$ \\
\hline $\mathrm{SH}^{15} \mathrm{~N}$ & 12.9 & 14.2 & 18.1 & $a b 45.2$ & $15.1 \pm 0.6 \mathrm{AB}$ \\
\hline Mean \pm SEM & $14.2 \pm 0.9 \mathrm{~b}$ & $12.4 \pm 0.9 \mathrm{~b}$ & $18.0 \pm 0.9 \mathrm{a}$ & $43.8 \pm 2.4$ & \\
\hline
\end{tabular}

Means followed by a different letter lower-case letter, in the rows, and upper-case letter, in the columns, are different by the Tukey-Kramer (P $\leq 0.1)$. Means followed by superscript letters differ vertically by the Tukey-Kramer $(\mathrm{p} \leq 0.1)$. ${ }^{1}$ Cane was planted on $01 \mathrm{Mar} 2001$. POL $=$ apparent sucrose content in the cane juice. ${ }^{2}$ Treatments: $\mathrm{AS}^{15} \mathrm{~N}$ ( ${ }^{15} \mathrm{~N}$-labeled ammonium sulfate); $\mathrm{SH}+\mathrm{AS}^{15} \mathrm{~N}$ (sunn hemp $+{ }^{15} \mathrm{~N}$-labeled ammonium sulfate); $\mathrm{SH}{ }^{15} \mathrm{~N}\left({ }^{15} \mathrm{~N}-\mathrm{labeled}\right.$ sunn hemp). ${ }^{3}$ Standard error of the mean. Adapted from [15].

[60] showed evidence of the positive effect of green manure fertilization with sunn hemp in sugarcane, with greater sugarcane yield increase than with the application of $40 \mathrm{~kg} \cdot \mathrm{ha}^{-1}$ mineral $\mathrm{N}$ to the soil. [18], studying lupine in maize, and [13], studying velvet bean and sunn hemp in rice, could not find response to mineral $\mathrm{N}$ applied after green manure. and no $\mathrm{N}$ fertilizer was needed when vetch (Vicia spp.) was grown after wheat, and when cotton followed fava beans [61].

The effect of fertilizer source on sugar concentration was less evident. In the average of three cuttings, the value of pol in plots, treated with both $\mathrm{AS}+\mathrm{SH}$ was higher than in that observed in plots that received no $\mathrm{N}$ (Table 18). Pol in cane juice was higher in the third cutting than in the two previous ones. Variations in pol measurements among cropping seasons are usually more affected by environmental conditions (temperature and drought) that determine cane maturation than by nutrition. However, high $\mathrm{N}$ tends to decrease sugar content and delay maturation [62]; therefore, after two years with no $\mathrm{N}$ fertilization, sugar content in cane plants was more likely to be high.

The recovery of $\mathrm{N}$ by the first two consecutive harvests accounted for $19 \%$ to $21 \%$ of the $\mathrm{N}$ applied as leguminous green manure and $46 \%$ to $49 \%$ of the $\mathrm{N}$ applied as AS.

Nitrogen derived from AS and SH in the leaves and top parts of the sugarcane plant, excluding the stalks, varied from $6.9 \%$ to $12.3 \%$ of the total $\mathrm{N}$ at the end of the first cycle (plant cane) and was not affected by $\mathrm{N}$ source (Table 19). But the amounts of $\mathrm{N}$ from both sources accumulated in the leaves and tops were in the range of only 4.5 to $6.0 \mathrm{~kg} \cdot \mathrm{ha}^{-1}$, which represent a recovery of $6.4 \%$ to $8.1 \%$ of the N applied as AS and $2.7 \%$ 
and $3.1 \%$ of the $\mathrm{N}$ from the green manure (Table 19). The recovery of ${ }^{15} \mathrm{~N}$ in the second cycle decreased when the $\mathrm{N}$ source was the inorganic fertilizer. In the second year the percentage of $\mathrm{N}$ derived from sunn hemp was greater than that from the AS, indicating a slightly higher residual effect of the green manure (Table 19).

The percentage of $\mathrm{N}$ derived from the AS or $\mathrm{SH}$ accumulated in the stalks harvested in the first cycle were similar and ranged from $7.0 \%$ to $10.5 \%$ of the total $\mathrm{N}$ content. In the plant cane cycle the amounts of $\mathrm{N}$ in the stalks that had been applied as inorganic or organic fertilizers were higher than those measured in the leaves and tops and varied from 27.3 to $24.1 \mathrm{~kg} \cdot \mathrm{N} \cdot \mathrm{ha}^{-1}$ (Table 20). The recovery of $\mathrm{N}$ derived from inorganic fertilizer-30.1\% to $34.4 \%$ - was higher than that of the sunn hemp $-8.8 \%$ to $9.8 \%$. However, in the second harvest the $\mathrm{N}$ the green manure supplied more $\mathrm{N}$ to the cane stalk than AS (Table 20). The difference in the amounts of $\mathrm{N}$ in the sugarcane plants derived from green manure and mineral fertilizer in the ratoon crop was around 1 to 2 $\mathrm{kg} \cdot \mathrm{ha}^{-1} \mathrm{~N}$ in leaves and tops (Table 19) and 4 to 7 $\mathrm{kg} \cdot \mathrm{N} \cdot \mathrm{ha}^{-1}$ in the stalks (Table 12), which were relatively small compared to the amounts of $\mathrm{N}$ accumulated in the ratoon plants $\left(179 \mathrm{~kg} \cdot \mathrm{N} \cdot \mathrm{ha}^{-1}\right.$ in plants supplied with AS and $243 \mathrm{~kg} \cdot \mathrm{ha}^{-1} \cdot \mathrm{N}$ in the $\mathrm{SH}$ treatments, or a $64 \mathrm{~kg} \cdot \mathrm{N} \cdot \mathrm{ha}^{-1}$ difference - Table 20). These results suggest that the effect of green manure on the yield of the second ratoon crop (Table 18) may not be only due to the extra N supply, but rather to other beneficial role of green manure on soil physical-chemical or biological activity properties.

Adding up the amounts of $\mathrm{N}$ taken up by the sugarcane plant and contained in the above-ground parts of the plant (leaves, tops and stalks), AS supplied 32.4 to 34.2 $\mathrm{kg} \cdot \mathrm{N} \cdot \mathrm{ha}^{-1}$ or about $46 \%$ to $49 \%$ of $\mathrm{N}$ recovery; the $\mathrm{N}$ taken up by sugarcane from sunn hemp varied from 37.4 to $40.0 \mathrm{~kg} \cdot \mathrm{ha}^{-1}$, which represented $19.1 \%$ to $20.8 \% \mathrm{~N}$ recovery (Tables 19 and 20).

The recovery of $\mathrm{N}$ from fertilizers by sugarcane is

Table 19. Percentage (Ndff) and quantity (QNdff) of nitrogen in leaves derived from the labeled fertilizer source in samples taken in the first and second harvests ${ }^{1}$.

\begin{tabular}{|c|c|c|c|c|c|}
\hline \multirow{2}{*}{$\begin{array}{l}\text { Sampling } \\
\text { dates }\end{array}$} & \multicolumn{4}{|c|}{ Treatments $^{2}$} & \multirow{2}{*}{ Mean $\pm \mathrm{SEM}^{3}$} \\
\hline & $\mathrm{AS}^{15} \mathrm{~N}$ & $\mathrm{SH}-{ }^{15} \mathrm{~N}+\mathrm{AS}$ & $\mathrm{SH}^{15} \mathrm{~N}$ & $\mathrm{AS}^{15} \mathrm{~N}+\mathrm{SH}$ & \\
\hline & \multicolumn{5}{|c|}{ Ndff, $\%$} \\
\hline 24 Aug 2002 & $12.3 \mathrm{Aa}$ & $11.1 \mathrm{Aa}$ & $10.9 \mathrm{Aa}$ & $6.9 \mathrm{Aa}$ & $10.3 \pm 1.1$ \\
\hline 08 Oct 2003 & $1.7 \mathrm{Bb}$ & $5.5 \mathrm{Aa}$ & 4.1 Aab & $1.7 \mathrm{Bb}$ & $3.2 \pm 1.1$ \\
\hline \multirow[t]{2}{*}{ Mean \pm SEM } & $7.0 \pm 1.6$ & $8.3 \pm 1.6$ & $7.5 \pm 1.6$ & $4.3 \pm 1.6$ & \\
\hline & \multicolumn{5}{|c|}{ QNdff, $\mathrm{kg} \cdot \mathrm{ha}^{-1}$} \\
\hline 24 Aug 2002 & 5.7 & 6.0 & 5.2 & 4.5 & $5.4 \pm 0.6 \mathrm{~A}$ \\
\hline 08 Oct 2003 & 1.8 & 6.8 & 4.6 & 2.9 & $4.0 \pm 0.6 \mathrm{~A}$ \\
\hline Mean \pm SEM & $3.7 \pm 1.0 \mathrm{a}$ & $6.4 \pm 1.0 \mathrm{a}$ & $4.9 \pm 1.0 \mathrm{a}$ & $3.7 \pm 1.0 \mathrm{a}$ & \\
\hline
\end{tabular}

Means followed by a different letter lower-case letter, in the rows, and upper-case letter, in the columns, are different by the Tukey-Kramer and $\mathrm{F}$ tests ( $\mathrm{P} \leq 0.1)$, respectively. ${ }^{1}$ Cane was planted on 01 Mar $2001 .{ }^{2}$ Treatments: $\mathrm{AS}^{15} \mathrm{~N}\left({ }^{15} \mathrm{~N}\right.$-labeled ammonium sulfate); $\mathrm{SH}+\mathrm{AS}{ }^{15} \mathrm{~N}\left(\mathrm{sunn}\right.$ hemp $+{ }^{15} \mathrm{~N}-$ labeled ammonium sulfate); $\mathrm{SH}^{15} \mathrm{~N}\left({ }^{15} \mathrm{~N}\right.$-labeled sunn hemp). ${ }^{3}$ Standard error of the mean. Adapted from [15].

Table 20. Percentage (Ndff) and quantity (QNdff) of nitrogen derived from the labeled fertilizer source, in samplings carried out in the first and second harvestings ${ }^{1}$.

\begin{tabular}{|c|c|c|c|c|c|}
\hline \multirow{2}{*}{ Sampling dates } & \multicolumn{4}{|c|}{ Treatments $^{2}$} & \multirow{2}{*}{ Mean $\pm \mathrm{SEM}^{3}$} \\
\hline & $\mathrm{AS}^{15} \mathrm{~N}$ & $\mathrm{SH}{ }^{15} \mathrm{~N}+\mathrm{AS}$ & $\mathrm{SH}^{15} \mathrm{~N}$ & $\mathrm{AS}^{15} \mathrm{~N}+\mathrm{SH}$ & \\
\hline & \multicolumn{5}{|c|}{ Ndff, \% } \\
\hline 24 Aug 2002 & $10.5 \mathrm{Aa}$ & 7.0 Aa & $8.2 \mathrm{Aa}$ & 10.3 Aa & $9.0 \pm 1.2$ \\
\hline 08 Oct 2003 & $1.4 \mathrm{Bb}$ & $3.8 \mathrm{Aa}$ & $3.7 \mathrm{Aa}$ & $1.7 \mathrm{Bb}$ & $2.6 \pm 0.1$ \\
\hline \multirow[t]{2}{*}{ Mean \pm SEM } & $6.0 \pm 1.2$ & $5.4 \pm 1.2$ & $5.9 \pm 1.2$ & $6.0 \pm 1.2$ & \\
\hline & \multicolumn{5}{|c|}{ QNdff, $\mathrm{kg} \cdot \mathrm{ha}^{-1}$} \\
\hline 24 Aug 2002 & $24.1 \mathrm{Aa}$ & $19.3 \mathrm{Aa}$ & 17.3 Aa & $21.1 \mathrm{Aa}$ & $20.4 \pm 2.78$ \\
\hline 08 Oct 2003 & $2.7 \mathrm{Bb}$ & $8.6 \mathrm{Aa}$ & 10.3 Aa & $3.9 \mathrm{Bb}$ & $6.4 \pm 0.8$ \\
\hline Média \pm SEM & $13.4 \pm 2.6$ & $14.0 \pm 2.6$ & $13.8 \pm 2.6$ & $12.5 \pm 2.6$ & \\
\hline
\end{tabular}

Means followed by a different letter lower-case letter, in the rows, and upper-case letter, in the columns, are different by the Tukey-Kramer and $\mathrm{F}$ tests ( $\mathrm{P} \leq 0.1$ ). ${ }^{1}$ Cane was planted on 01 Mar 2001. ${ }^{2}$ Treatments: $\mathrm{AS}^{15} \mathrm{~N}\left({ }^{15} \mathrm{~N}\right.$-labeled ammonium sulfate); $\mathrm{SH}+\mathrm{AS}^{15} \mathrm{~N}$ (sunn hemp $+{ }^{15} \mathrm{~N}$-labeled ammonium sulfate); $\mathrm{SH} \mathrm{H}^{15} \mathrm{~N}$ $\left({ }^{15} \mathrm{~N}\right.$-labeled sunn hemp). ${ }^{3}$ Standard error of the mean. Adapted from [15]. 
usually lower than that of grain crops: the latter varies from $50 \%$ to $70 \%$ [63] whereas for sugarcane the figures vary from $20 \%$ to $40 \%$ [64-66]. Results of several studies show that the utilization of $\mathrm{N}$ from green manure by subsequent crops rarely exceeds $20 \%$ [8,14,18,53] and most of the $\mathrm{N}$ remains in the soil, incorporated in the organic matter fraction. In the present study the application of AS along with $\mathrm{SH}$ increased $\mathrm{N}$ utilization by sugarcane plants. This result is in line with that of [13] who used an organic source isolated or combined with an inorganic fertilizer in rice crops and concluded that the green manures improved the mineral $\mathrm{N}$ utilization, resulting in $\mathrm{N}$ use efficiency of up to $79 \%$.

In a study in pots [14] observed that maize plants took up more $\mathrm{N}$ from sunn hemp incorporated to a sandy soil (Paleudalf) than to a clayey soils (Eutrudox) and that the $\mathrm{N}$ derived from the roots was more recalcitrant than that of the shoots. Between $50 \%$ and $68 \%$ of the ${ }^{15} \mathrm{~N}$ of the sunn hemp shoots remained in the soil whereas the figures for roots varied from $65 \%$ to $80 \%$; unaccounted for ${ }^{15} \mathrm{~N}$, probably lost in gaseous forms, varied from $5 \%$ to $15 \%$ of the sunn hemp $\mathrm{N}$ [14].

In a detailed account of the first year of the present experiment, [8] showed that 8 months after planting, the recovery by sugarcane plants (above ground parts) of the $\mathrm{N}$ derived from AS or from sunn hemp was similar: $3 \%$ to $6 \%$ of the added N. However, 12 and 15-month-old sugarcane plants recovered between $20 \%$ and $35 \%$ of the AS but only $6 \%$ to $8 \%$ of the sunn hemp-derived $\mathrm{N}$.

The percentage of recovery of the inorganic fertilizer $\mathrm{N}$ contained in the stalk when the sugarcane plants were harvested after 18 months of planting varied from $30 \%$ to $34 \%$; the corresponding figures for the $\mathrm{N}$ derived from sunn hemp were significantly lower: around $9 \%$ to $10 \%$ (Table 20). The residual effect of the $\mathrm{N}$ from both sources in the second harvest of the sugarcane plant was similar: between $4 \%$ and $6 \%$ of the $\mathrm{N}$ supplied at planting as AS or SH was recovered in the stalks of the sugarcane plant 31 months after planting (Table 19).

In the present study, about $69 \%$ of the $\mathrm{N}$ present in the sunn hemp residues were from BNF.

Perin [67] found substantial amounts of $\mathrm{N}$ derived from BNF present in the above ground parts of sunn hemp (57.0\%) grown isolated and $61.1 \%$ when intercropped with millet (Pennisetum glaucum, (L.) R. Brown) (50\% seeded with each crop). The sunn hemp + millet treatment grown before a maize crop resulted in higher grain yield than when sunn hemp alone was the preceding rotation. This effect was not observed when $\mathrm{N}$-fertilizer $\left(90 \mathrm{~kg} \cdot \mathrm{N} \cdot \mathrm{ha}^{-1}\right)$ was added; Perin [67] concluded that intercropping legume and cereals is a promising biological strategy to increase and keep $\mathrm{N}$ into production system under tropical conditions.

No difference was observed in relation to the cumula- tive $\mathrm{N}$ listed in Table 9. The cumulative $\mathrm{N}$ results are similar to those found by [64], who obtained, during plant cane harvesting, mean values of $252.3 \mathrm{~kg} \cdot \mathrm{ha}^{-1} \mathrm{cu}-$ mulative nitrogen, with high nitrogen and plant material accumulation during the last three months, as also observed by [65]. The nitrogen contents found in the aboveground part of sugarcane, Table 17, are in agreement with results of [64].

As the amounts of $\mathrm{N}$ applied as $\mathrm{AS}$ or $\mathrm{SH}$ to sugarcane in the first cycle were different $\left(70 \mathrm{~kg} \cdot \mathrm{N} \cdot \mathrm{ha}^{-1}\right.$ as AS and $196 \mathrm{~kg} \cdot \mathrm{N} \cdot \mathrm{ha}^{-1}$ as $\mathrm{SH}$ ), the quantities of $\mathrm{N}$ derived from the green manure in the second harvest were larger than those from the inorganic fertilizer, although the percentage of $\mathrm{N}$ recovery was similar (Table 19).

Because less $\mathrm{N}$ derived from the green manure was recovered by the sugarcane plant in the first cycle it would be expected that a higher proportion of that $\mathrm{N}$ would be taken up in the second cycle (first ratoon), but this did not happen. It seems that the residual $\mathrm{N}$ that is incorporated to the soil organic matter has a somewhat long turnover. Other authors have reported low recovery (about $3.5 \%$ of the $\mathrm{N}$ ) by the second crop after sunn hemp cover crop [68] or hairy vetch (Vicia villosa Roth) plowed into the soil [69]. Low recovery of residual $\mathrm{N}$ has also been observed for inorganic fertilizer sources: less than $3 \%$ of the $\mathrm{N}$ derived from fertilizers was taken up by soybeans (Glicine max (L) Merril) [70], maize (Zea Mays L.) [68], [69] or sugarcane (Saccharum spp.) [71], results similar to those obtained in the present study (Tables 19 and 20).

The amounts of inorganic $\mathrm{N}$, derived from both $\mathrm{N}$ sources, present in the $0-0.4 \mathrm{~m}$ layer of soil in the first season after $\mathrm{N}$ application and were below $1 \mathrm{~kg} \cdot \mathrm{ha}^{-1}$.

The average concentration of inorganic nitrogen in the $0-40 \mathrm{~cm}$ layer of soil was relatively low in most samples taken after $8,12,15$, and 18 months of planting (Table 21). Samples taken in February, in the middle of the rainy and hot season, presented somewhat higher values of $\left(\mathrm{NH}^{4+}+\mathrm{NO}^{3-}\right)-\mathrm{N}$ probably reflecting higher mineralization of soil organic N (Figure 3). Later in the growing season (samples of May and Aug 2002) soil inorganic $\mathrm{N}$ content decreased again. This coincides with beginning of the dry season with mild temperatures, when the sugarcane plant reached maturity and probably had already depleted the soil for most of the available N.

The percentage of the inorganic $\mathrm{N}$ derived from AS or $\mathrm{SH}$ present in the soil from the $8^{\text {th }}$ to the $18^{\text {th }}$ month after sugarcane planting represented only $1 \%$ to $9 \%$ of total inorganic $\mathrm{N}$ (Table 22). The proportion of $\mathrm{N}$ that was originated from AS decreased with time whereas that from the green manure increased, indicating that the mineralization of this organic source could supply more $\mathrm{N}$ at the end of the season (Table 14). Indeed, [11] showed that sugarcane stalks sampled in 15-month-old 


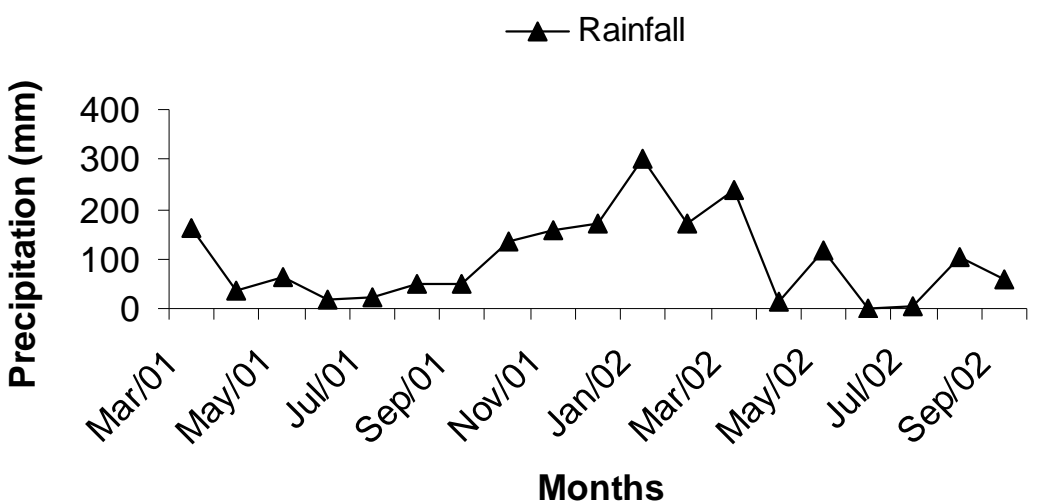

(a)
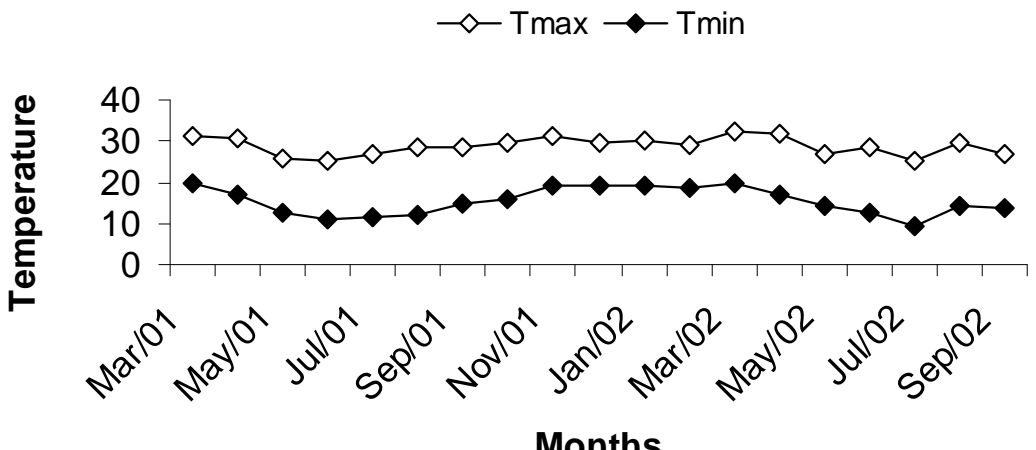

(b)

Figure 3. Climatic data for maximum and minimum temperature and rainfall during the first sugarcane growing season. Adapted from [15].

Table 21. Soil mineral $\mathrm{N}\left(\mathrm{NH}^{4+}+\mathrm{NO}^{3-}\right)$ determined in four sampling dates during the plant cane cycle. Data are average of samplings of the $0-0.2$ and $0.2-0.4 \mathrm{~m}$ soil layers.

\begin{tabular}{cccccc}
\hline & \multicolumn{5}{c}{ Sampling dates } \\
\multirow{2}{*}{ Treatments $^{1}$} & 29 Oct 2001 & $20 \mathrm{Feb} 2002$ & $28 \mathrm{May} 2002$ & 24 Aug 2002 & \\
\cline { 2 - 5 } & & & $\mathrm{mg} \cdot \mathrm{kg}^{-1}$ & \\
\hline Control & $2.7 \mathrm{Ab}$ & $7.3 \mathrm{ABa}$ & $2.3 \mathrm{Ab}$ & $2.8 \mathrm{Ab}$ & $3.8 \pm 0.22$ \\
$\mathrm{AS}^{15} \mathrm{~N}$ & $2.6 \mathrm{Ab}$ & $9.1 \mathrm{Aa}$ & $2.2 \mathrm{Ab}$ & $3.2 \mathrm{Ab}$ & $4.3 \pm 0.22$ \\
$\mathrm{SH}^{15} \mathrm{~N}+\mathrm{AS}$ & $2.9 \mathrm{Ab}$ & $7.0 \mathrm{ABa}$ & $2.7 \mathrm{Ab}$ & $3.1 \mathrm{Ab}$ & $3.9 \pm 0.22$ \\
$\mathrm{SH}^{15} \mathrm{~N}$ & $2.8 \mathrm{Ab}$ & $5.8 \mathrm{Ba}$ & $1.5 \mathrm{Bc}$ & $2.8 \mathrm{Ab}$ & $3.2 \pm 0.22$ \\
$\mathrm{SH}+\mathrm{AS}{ }^{15} \mathrm{~N}$ & $2.7 \mathrm{Ab}$ & $7.2 \mathrm{ABa}$ & $3.1 \mathrm{Ab}$ & $2.6 \mathrm{Ab}$ & $3.9 \pm 0.22$ \\
$\mathrm{Mean} \pm \mathrm{SEM}$ & $2.7 \pm 0.19$ & $7.3 \pm 0.19$ & $2.4 \pm 0.19$ & $2.9 \pm 0.19$ & \\
\hline
\end{tabular}

Means followed by a different letter lower-case letter, in the rows, and upper-case letter, in the columns, are different by the Tukey-Kramer ( $\mathrm{P} \leq 0.1$ ). ${ }^{1}$ Treatments: Control (no $\mathrm{N}$ fertilizer applied); $\mathrm{AS}^{15} \mathrm{~N}\left({ }^{15} \mathrm{~N}\right.$-labeled ammonium sulfate); $\mathrm{SH}+\mathrm{AS}^{15} \mathrm{~N}$ (sunn hemp $+{ }^{15} \mathrm{~N}-$ labeled ammonium sulfate); $\mathrm{SH}{ }^{15} \mathrm{~N}$ $\left({ }^{15} \mathrm{~N}\right.$-labeled sunn hemp). ${ }^{2}$ Standard error of the mean. Adapted from [15].

plants had significantly higher percentage of $\mathrm{N}$ derived from AS than from $\mathrm{SH}$; in the $18^{\text {th }}$ month that difference had disappeared. Nonetheless, throughout the season, the amounts of inorganic $\mathrm{N}$ in the soil derived from either AS or SH were of very little significance for the nutrition of the sugarcane plant-less than $1 \mathrm{~kg} \cdot \mathrm{ha}^{-1}$ of inorganic $\mathrm{N}$ in a $40 \mathrm{~cm}$ soil layer (Table 22), indicating that little residual $\mathrm{N}$ is expected in soils grown with this crop. Although the rate of $\mathrm{N}$ applied as $\mathrm{SH}$ was almost 200 $\mathrm{kg} \cdot \mathrm{N} \cdot \mathrm{ha}^{-1}$, little nitrate leaching losses are expected under the conditions of this experiment.

Soil $\mathrm{N}$ is often the most limiting element for plant growth and quality. Therefore, green manure may be useful for increasing soil fertility and crop production. With regard to fertilization, organic matter such as a green manure can be potentially important sources of $\mathrm{N}$ for crop production [72].

Sugarcane is a fast growing plant that produces high 
Table 22. Percent (Ndff) and amount (QNdff) of soil mineral $\mathrm{N}\left(\mathrm{NH}^{4+}+\mathrm{NO}^{3-}\right)$ derived from the labeled fertilizer source (Ndff). Data are average of samplings of the $0-0.2$ and $0.2-0.4 \mathrm{~m}$ soil layers.

\begin{tabular}{|c|c|c|c|c|c|}
\hline \multirow{2}{*}{ Treatments $^{1}$} & \multicolumn{4}{|c|}{ Sampling dates } & \multirow{2}{*}{ Mean $\pm \mathrm{SEM}^{2}$} \\
\hline & 29 Oct 2001 & $20 \mathrm{Feb} 2002$ & 28 May 2002 & 24 Aug 2002 & \\
\hline & \multicolumn{5}{|c|}{ Ndff, $\%$} \\
\hline $\mathrm{AS}^{15} \mathrm{~N}$ & $5.9 \mathrm{Aa}$ & $0.7 \mathrm{Aa}$ & $3.2 \mathrm{Aa}$ & $1.0 \mathrm{Ba}$ & $2.7 \pm 0.57$ \\
\hline $\mathrm{SH}^{15} \mathrm{~N}+\mathrm{AS}$ & $2.6 \mathrm{Ab}$ & $3.2 \mathrm{Aab}$ & $9.0 \mathrm{Aa}$ & 5.7 ABab & $5.1 \pm 0.62$ \\
\hline $\mathrm{SH}^{15} \mathrm{~N}$ & $2.9 \mathrm{Aa}$ & $4.3 \mathrm{Aa}$ & 7.0 Aa & $5.9 \mathrm{Aa}$ & $5.0 \pm 0.58$ \\
\hline $\mathrm{SH}+\mathrm{AS}^{15} \mathrm{~N}$ & $2.9 \mathrm{Aa}$ & $0.3 \mathrm{Aa}$ & $4.0 \mathrm{Aa}$ & $1.3 \mathrm{ABa}$ & $2.1 \pm \quad 0.62$ \\
\hline \multirow[t]{2}{*}{ Mean \pm SEM } & $3.6 \pm 0.58$ & $2.1 \pm 0.56$ & $5.8 \pm 056$ & $3.5 \pm 0.55$ & \\
\hline & \multicolumn{5}{|c|}{ QNdff, $\mathrm{kg} \cdot \mathrm{ha}^{-1}$} \\
\hline $\mathrm{AS}^{15} \mathrm{~N}$ & $0.3 \mathrm{Aa}$ & $0.3 \mathrm{Aa}$ & $0.4 \mathrm{Aa}$ & $0.5 \mathrm{Aa}$ & $0.40 \pm 0.16$ \\
\hline $\mathrm{SH}^{15} \mathrm{~N}+\mathrm{AS}$ & $0.1 \mathrm{Aa}$ & $0.2 \mathrm{Aa}$ & $0.2 \mathrm{Aa}$ & $0.2 \mathrm{Aa}$ & $0.18 \pm 0.18$ \\
\hline $\mathrm{SH}^{15} \mathrm{~N}$ & $0.1 \mathrm{Aa}$ & $0.2 \mathrm{Aa}$ & $0.1 \mathrm{Aa}$ & $0.2 \mathrm{Aa}$ & $0.15 \pm 0.16$ \\
\hline $\mathrm{SH}+\mathrm{AS}^{15} \mathrm{~N}$ & $0.1 \mathrm{Aa}$ & $0.1 \mathrm{Aa}$ & $0.1 \mathrm{Aa}$ & $0.0 \mathrm{Aa}$ & $0.07 \pm 0.16$ \\
\hline Mean \pm SEM & $0.15 \pm 0.09$ & $0.21 \pm 0.09$ & $0.24 \pm 0.09$ & $0.22 \pm 0.09$ & \\
\hline
\end{tabular}

For Ndff: means followed by a different letter lower-case letter, in the rows, and upper-case letter, in the columns, are different by the Tukey-Kramer and F tests $(\mathrm{P} \leq 0.1)$, respectively. For Qndff: means followed by a different letter lower-case letter, in the rows, and upper-case letter, in the columns, are different by the Tukey-Kramer test $(\mathrm{P} \leq 0.1) .{ }^{1}$ Treatments: Control (no N fertilizer applied); $\mathrm{AS}^{15} \mathrm{~N}\left({ }^{15} \mathrm{~N}\right.$-labeled ammonium sulfate); $\mathrm{SH}+\mathrm{AS}{ }^{15} \mathrm{~N}\left(\right.$ sunn hemp $+{ }^{15} \mathrm{~N}-$ labeled ammonium sulfate); $\mathrm{SH}^{15} \mathrm{~N}\left({ }^{15} \mathrm{~N}\right.$-labeled sunn hemp). ${ }^{2}$ Standard error of the mean. Adapted from [15].

amounts of dry matter. Therefore, it tends to rapidly deplete the soil of inorganic $\mathrm{N}$, especially in soils fertilized with small rates of soluble $\mathrm{N}$ as in the case of this study. Cantarella [66] reviewed several Brazilian studies showing little nitrate leaching losses in sugarcane. More recently, [73] showed that only $0.2 \mathrm{~kg} \cdot \mathrm{ha}^{-1} \mathrm{NO}^{3-}-\mathrm{N}$ derived from $120 \mathrm{~kg} \cdot \mathrm{ha}^{-1}$ of $\mathrm{N}$ as urea enriched to $5.04{ }^{15} \mathrm{~N} \mathrm{At} \%$ applied to the planting furrow leached below $0.9 \mathrm{~m}$ in a sugarcane field, although the total $\mathrm{N}$ loss reached 18 $\mathrm{kg} \cdot \mathrm{ha}^{-1} \cdot \mathrm{N}$, mostly derived from soil organic matter mineralization or residual $\mathrm{N}$ already present in the soil. As in the present study, the data of [73] refer to $\mathrm{N}$ applied at the end of the rainy season when excess water percolating through the soil profile is limited (Figure 3).

\section{CONCLUSIONS}

Velvet bean green manure, especially the aboveground parts, presented the greatest contribution to the inorganic $\mathrm{N}$ in the soil;

Common Bean residue trash added to the soil caused the immobilization of inorganic N;

Green manure incorporated to the soil was more intensively mineralized, preventing the soil native organic $\mathrm{N}$ be mineralized.

Legume $\mathrm{N}$ mineralization was higher in the Paleudalf.

The supply of $\mathrm{N}$ by the green manure was constant during the development of the corn plant;

The highest $\mathrm{N}$ losses were verified for the Velvet bean in the Paleudalf soil.

The biomass of sunn hemp induced a complete N substitution in sugarcane and could positively affect yield and increase $\mathrm{Ca}$ and $\mathrm{Mg}$ contents, sum of bases, $\mathrm{pH}$, and base saturation, and decrease potential acidity and increase profit.

The combination of inorganic fertilizer and green manure resulted in higher sugarcane yields than either $\mathrm{N}$ source separately. The recovery of $\mathrm{N}$ from ammonium sulfate was higher in the first year whereas in the green manure presented a longer residual effect and resulted in higher yields of cane in the second cycle.

Very little inorganic $\mathrm{N}$ was presented in the $0-40 \mathrm{~cm}$ soil layer with both $\mathrm{N}$ sources.

\section{ACKNOWLEDGEMENTS}

To the technical research support of Gilberto Farias, Benedito Mota, and Maria Aparecida C. de Godoy. To FAPESP and CNPq for the grants. Piraí seeds for green manure and cover crops and Fundag for the support.

\section{REFERENCES}

[1] Pankhurst, C.E., Stirling, G.R., Magarey, R.C., Blair, B.C., Holt, J.A., Bell, M.J. and Garside, A.L. (2005) Quantification of the effects of rotation breaks on soil biological properties and their impact on yield decline in sugarcane. Soil Biology and Biochemistry, 37, 1121-1130. http://dx.doi.org/10.1016/j.soilbio.2004.11.011

[2] Shoko, M.D. and Zhou, M. (2009) Nematode diversity in a soybean-sugarcane production system in a semi-arid region of Zimbabwe. Journal of Entomology and Nematology, 1, 25-28.

[3] Garside, A.L., Berthelsen, J.E., Richards, C.L. and Toovey, 
L.M. (1996) Fallow legumes on the wet tropical coast: Some species and management options. Proceedings of the Australian Society of Sugar Cane Technologists, 18, 202208.

[4] Shoko, M.D. and Tawira, F. (2007) Benefits of soyabeans as a breakcrop in sugarcane production systems in the South Eastern Lowveld of Zimbabwe. Sugar Journal, 70, 18-22.

[5] Mc Mahon, G.G., Williams, R.C. and Mc Guire, P.J. (1989) The effects of weed competition on ratoon sugar cane yield. Proceedings of the Australian Society of Sugar Cane Technologists, 10, 88-92.

[6] Cheruiyot, E.K., Mumera, L.M., Nakhone, L.N. and Mwonga, S.M. (2003) Effect of legumemanaged fallow on weeds and soil nitrogen in following maize (Zea mays L.) and wheat (Triticum aestivum L.) crops in the Rift Valley highlands of Kenya. Australian Journal of Experimental Agriculture, 43, 597-604. http://dx.doi.org/10.1071/EA02033

[7] Jannink, J.L., Liebman, M. and Merrick, L.C. (1996) Biomass production and nitrogen accumulation in pea, oat, and vetch green manure mixtures. Agronomy Journal, 88, 231-240.

http://dx.doi.org/10.2134/agronj1996.0002196200880002 $\underline{0019 x}$

[8] Ambrosano, E.J., Trivelin, P.C.O., Cantarella, H., Ambrosano, G.M.B., Schammass, E.A., Guirado, N., Rossi, F., Mendes, P.C.D. and Muraoka, T. (2005) Utilization of nitrogen from green manure and mineral fertilizer by sugarcane. Scientia Agricola, 62, 534-542. http://dx.doi.org/10.1590/S0103-90162005000600004

[9] IBGE (2010) Systematic survey of agricultural production.

http://www.sidra.ibge.gov.br/bda/default.asp? $\mathrm{t}=5 \& \mathrm{z}=\mathrm{t} \& \mathrm{o}=1 \&$ u $1=1 \&$ u $2=1 \&$ u $3=1 \&$ u $4=1$ $\& \mathrm{u} 5=1 \quad \& \quad \mathrm{u} \quad 6=1 \quad \& \quad \mathrm{u} \quad 7=$ $1 \& u 8=1 \& u 9=3 \& u 10=1 \& u 11=26674 \& u 12=1 \& u 13=1 \& u$ $\underline{14=1}$

[10] Ambrosano, E.J., Azcón, R., Ambrosano, G.M.B., Cantarella, H., Guirado, N., Muraoka, T., Rossi, F., Schammass, E.A., Trivelin, P.C.O., Ungaro, M.R. and Teramoto, S.J.R. (2010) Crop rotation biomass and arbuscular mycorrhizal fungi effects on sugarcane yield. Scientia Agricola, 67, 692701.

[11] Dinardo-Miranda, L.L. and Fracasso, J.V. (2009) Spatial distribution of plantparasitic nematodes in sugarcane fields. Scientia Agricola, 66, 188-194. http://dx.doi.org/10.1590/S0103-90162009000200007

[12] Ambrosano, E.J., Ambrosano, G.M.B., Azcón, R., Cantarella, H., Dias, F.L.F., Muraoka, T., Trivelin, P.C.O., Rossi, F., Schammass, E.A. and Sachs R.C.C. (2011) Productivity of sugarcane after previous legumes crop. Bragantia, 70, 1-9. (in Portuguese, with abstract in English)

[13] Muraoka, T., Ambrosano, E.J., Zapata, F., Bortoletto, N., Martins, A.L.M., Trivelin, P.C.O., Boaretto, A.E. and Scivittaro, W.B. (2002) Efficiency of green manure (Crotalaria and Mucuna) and urea as nitrogen source for rice crop. Terra, 20, 17-23. (in Portuguese, with abstract in English)

[14] Ambrosano, E.J., Trivelin, P.C.O., Cantarella, H., Ambro- sano, G.M.B., Schammass, E.A., Muraoka, T., Guirado, N. and Rossi, F. (2009) Nitrogen supply to maize from sunn hemp and velvet bean green manures. Scientia Agricola, 66, 386-394

http://dx.doi.org/10.1590/S0103-90162009000300014

[15] Ambrosano, E.J., Trivelin, P.C.O., Cantarella, H., Ambrosano, G.M.B., Schammass, E.A., Muraoka, T. and Rossi, F. (2011) ${ }^{15} \mathrm{~N}$-labeled nitrogen from green manure and ammonium sulfate utilization by the sugarcane ratoon. Scientia Agricola, 68, 361-368. http://dx.doi.org/10.1590/S0103-90162011000300014

[16] Albuquerque, G.A.C., Araújo Filho, J.T. and Marinho, M.L. (1980) Green manure and its economic importance. Buletim IAA/PLANALSUCAR, 1, 1-10. (in Portuguese)

[17] Mascarenhas, H.A.A., Nogueira, S.S.S., Tanaka, R.T., Martins, Q.A.C. and Carmello, Q.A.C. (1998) Effect of productivity of crop rotation and summer and sunn henp in the winter. Scientia Agricola, 55, 534-537. (in Portuguese, with abstract in English) http://dx.doi.org/10.1590/S0103-90161998000300024

[18] Kanthack, R.A.D., Mascarenhas, H.A.A., Castro, O.M. and Tanaka, R.T. (1991) Nitrogen applied as side dressing in corn after white lupine. Brazilian Agricultural Research, 26, 99-104. (in Portuguese, with abstract in English)

[19] Ambrosano, E.J, Trivelin, P.C.O., Cantarella, H., Ambrosano, G.M.B. and Muraoka, T. (2003) Nitrogen mineralizetion in soils amended with sunnhemp, velvet bean and common bean residues. Scientia Agricola, 60, 133-137. http://dx.doi.org/10.1590/S0103-90162003000100020

[20] Ambrosano, E.J., Trivelin, P.C.O. and Muraoka, T. (1997) A technique developed for labeling the green manures (sunnhemp and velvet bean) with ${ }^{15} \mathrm{~N}$ for nitrogen dynamic studies. Bragantia, 56, 219-224. (in Portuguese, with abstract in English)

[21] Buresh, R.J., Austin, E.R. and Craswell, E.T. (1982) Analytical methods in ${ }^{15} \mathrm{~N}$ research. Fertilizer Research, 3, 37-62. http://dx.doi.org/10.1007/BF01063408

[22] Rittenberg, D. (1946) The preparation of gas sample for mass-spectrometric analysis. In Wilson, D.W., Ed., Preparation and Measure of Isotopic Tracers, Ann Arbor, Michigan, 31.

[23] International Atomic Energy Agency. (1976) Tracer manual on crops and soils. IAEA, Viena, 277. (Tecnical Reports Series, 171)

[24] Bremner, J.M. (1996) Nitrogen-total. In: Sparks, D.L., Ed., Methods of Soil Analysis, Part 3, Soil Science Society of America, Madison, 1085-1121.

[25] Proksch, G. (1969) Routine analysis of $15 \mathrm{~N}$ in plant material by mass-spectrometry. Plant and Soil, 31, 380-384. http://dx.doi.org/10.1007/BF01373583

[26] Trivelin, P.C.O., Salati, E. and Matsui, E. (1973) Preparation of samples for ${ }^{15} \mathrm{~N}$ analysis by mass spectrometry. USP/CENA, Piracicaba, 41. (Technical Bulletin, 2, in Portuguese, with abstract in English)

[27] Ambrosano, E.J., Trivelin, P.C.O., Cantarella, H., Rossetto, R., Muraoka, T., Bendassolli, J.A., Ambrosano, G.M.B., Tamiso, L.G., Vieira, F.C. and Prada Neto, I. (2003) Nitrogen-15 labeling of Crotalaria juncea green manure. Sci- 
entia Agricola, 60, 181-184.

[28] Tanimoto, T. (1964) The press method of cane analysis. Hawaiian Planter's Record, 57, 133-150.

[29] Trivelin, P.C.O., Lara Cabezas, W.A.R., Victoria, R.L. and Reichardt, K. (1994) Evaluation of a ${ }^{15} \mathrm{~N}$ plot design for estimating plant recovery of fertilizer nitrogen applied to sugar cane. Scientia Agricola, 51, 226-234. http://dx.doi.org/10.1590/S0103-90161994000200005

[30] Tanaka, R.T., Mascarenhas, H.A.A., Dias, O.S., Campide1li, C. and Bulisani, E.A. (1992) Soybean cultivation after incorporation of green manure and organic compost. Brazilian Agricultural Research, 27, 1477-1483. (in Portuguese, with abstract in English)

[31] Jans-Hammermeister, D.C., McGill, W.B. and Jensen, T.L. (1994) Nitrogen accumulations and relative rates of mineralization in two soils following legume green manuring. Canadian Journal of Soil Science, 74, 23-28. http://dx.doi.org/10.4141/cjss94-003

[32] Calvache Ulloa, A.M., Libardi, P.L. and Reichardt, K. (1982) Utilization of nitrogen fertilizer by two corn hybrids. Cargill Foundation, Campinas, 66.

[33] Fried, D.M. and Broeshart, H. (1974) Priming effect of nitrogen fertilizer on soil nitrogen. Proceedings of the Soil Science Society of America, 38, 858-864. http://dx.doi.org/10.2136/sssaj1974.03615995003800050 $\underline{046 x}$

[34] Jenkinson, D.S., Fox, R.H. and Rayner, J.H. (1985) Interaction between fertilizer nitrogen and soil nitrogen-The so-called "Priming" effect. Journal of Soil Science, 36, 425-444. http://dx.doi.org/10.1111/j.1365-2389.1985.tb00348.x

[35] Hart, P.B.S., Rayner, J.H. and Jenkinson, D.S. (1986) Influence of pool substitution on the interpretation of fertilizer experiments with ${ }^{15} \mathrm{~N}$. Journal of Soil Science, 37, 389403. http://dx.doi.org/10.1111/j.1365-2389.1986.tb00372.x

[36] Rao, A.C.S., Smith, J.L., Parr, J.F. and Papendick, R.J. (1992) Considerations in estimating nitrogen recovery efficiency by the difference and isotopic dilution methods. Fertilizer Research, 33, 209-217. http://dx.doi.org/10.1007/BF01050876

[37] Ambrosano, E.J., Ambrosano, G.M.B., Corsi, M., Cantarella, H., Trivelin, P.C.O. and Muraoka, T. (1996) Utilization of nitrogen by ammonium sulfate $\left({ }^{15} \mathrm{~N}\right)$ at grasscolonião at successive cuts in different seasons and fertilization. Brazilian Journal of Soil Science, 20, 277-282. (in Portuguese, with abstract in English)

[38] Stevenson, F.J. (1982) Nitrogen in agricultural soils. In: Organic Forms of Soil Nitrogem, ASA, Madison, 67-122.

[39] Ladd, J.N., Amato, M., Jackson, R.B. and Butler, J.H.A. (1983) Utilization by wheat crops of nitrogen from legume residues decomposing in soils in the field. Soil Biology and Biochemistry, 15, 231-238. http://dx.doi.org/10.1016/0038-0717(83)90064-0

[40] Stevenson, F.J. (1994) Humus chemistry: Genesis, composition, reactions. 2nd Edition, John Wiley, New York, 9597.

[41] Bayer, C., Mielniczuk, J., Martin-Neto, L. and Errnani, P.R.
(2004) Stocks and humification degree of organic matter fractions as affected by no-tillage on a subtropical soil. Plant and Soil, 238, 133-140.

[42] Bertoncini, E.I., D’Orazio, V., Senesi, N. and Mattiazzo, M.E. (2005) Fluorescence analysis of humic and fulvic acids from two Brazilian oxisols as affected by biosolid amendment. Analytical and Bioanalytical Chemistry, 381, 1281-1288. http://dx.doi.org/10.1007/s00216-005-3054-2

[43] Ladd, J.N., Oades, J.M. and Amato, M. (1981) Microbial biomass formed from ${ }^{14} \mathrm{C},{ }^{15} \mathrm{~N}$-labeled plant material decomposing in soils in the field. Soil Biology and Biochemistry, 13, 119-126. http://dx.doi.org/10.1016/0038-0717(81)90007-9

[44] Bartholomew, W.V. (1965) Mineralization and immobilization of nitrogem in the decomposition of plant and animal residues. In: Bartholomew, W.V. and Clark, F.E., Eds., Soil Nitrogen, American Society of Agronomy, Madison, 287-306. (American Society of Agronomy Monograph, 10)

[45] Flores, L.M. (1986) Quantitative evaluation of the efficiency of use of two nitrogen sources, $\mathrm{CO}\left({ }^{15} \mathrm{NH}_{2}\right)_{2} \mathrm{e}$ $\left({ }^{15} \mathrm{NH}_{4}\right)_{2} \mathrm{SO}_{4}$ by maize crops (Zea mays L.). Master's Thesis, USP/ESALQ, Piracicaba, 103.

[46] Villas Bôas, R.L. (1990) Alternatives to increase the recovery of urea nitrogen by corn (Zea mays L). Master's Thesis, USP/ESALQ, Piracicaba, 78.

[47] Ng Kee Kwong, K.F. and Deville, J. (1994) Application of ${ }^{15} \mathrm{~N}$-labelled urea to sugar cane through a drip-irrigation system in Mauritius. Fertilizer Research, 39, 223228. http://dx.doi.org/10.1007/BF00750250

[48] Farquhar, G.D., Wetselaar, R. and Firth, P.M. (1979) Ammonia volatilization from senescing leaves of maize. Science, 203, 1257-1258.

http://dx.doi.org/10.1126/science.203.4386.1257

[49] Stutte, C.A., Weiland, R.T. and Blem, A.R. (1979) Gaseous nitrogen loss from soybean foliage. Agronomy Journal, 71, 95-97.

[50] Silva, P.R.F. and Stutte, C.A. (1981) Nitrogem loss in conjunction with transpiration from rice leaves as influenced by growth stage, leaf position and $\mathrm{N}$ supply. Agronomy Journal, 73, 38-48.

http://dx.doi.org/10.2134/agronj1981.0002196200730001 $\underline{0009 x}$

[51] Allison, F.E. (1966) The fate of nitrogen applied to soils. Advances in Agronomy, 18, 219-258. http://dx.doi.org/10.1016/S0065-2113(08)60651-3

[52] Azam, F., Malik, K.A. and Sajjad, M.I. (1985) Transformations in soil and availability to plants of ${ }^{15} \mathrm{~N}$ applied as inorganic fertilizer and legume residues. Plant and Soil, 86, 3-13. http://dx.doi.org/10.1007/BF02185020

[53] Silva, E.C., Muraoka, T., Buzetti, S., Guimarães, G.L., Trivelin, P.C.O. and Veloso, M.E.C. (2006) Utilization of residual nitrogen $\left({ }^{15} \mathrm{~N}\right)$ by urea cover crops by corn. Brazilian Journal of Soil Science, 30, 965-974. (in Portuguese, with abstract in English)

[54] Ladd, J.N., Oades, J.M. and Amato, M. (1981) Distribution and recovery of nitrogem from legume residues decomposing in soils sown to wheat in the field. Soil Biology and Biochemistry, 13, 251-256. 
http://dx.doi.org/10.1016/0038-0717(81)90058-4

[55] Harris, G.H. and Hesterman, O.B. (1990) Quantifying the nitrogen contribution from alfafa to soil and two succeeding crops using nitrogen-15. Agronomy Journal, 82, 129134.

http://dx.doi.org/10.2134/agronj1990.0002196200820001 $\underline{0028 x}$

[56] Sakai, R.H., Ambrosano, E.J., Guirado, N., Rossi, F., Mendes, P.C.D., Cantarella, H., Arevalo, R.A. and Ambrosano, G.M.B. (2007) Agronomic evaluation of four species of mucuna used as green manure in agro ecological systems. Brazilian Journal of Agroecology, 2, 910-913. (in Portuguese, with abstract in English)

[57] Franchini, J.C., Meda, A.R., Cassiolato, M.E., Miyazawa, M. and Pavan, M.A. (2001) Plant residue extracts potential for lime mobility in the soil using a biological method. Scientia Agricola, 58, 357-360. http://dx.doi.org/10.1590/S0103-90162001000200020

[58] Humbert, R.P. (1968) Nutrition of sugar cane. In: The Growing of Sugar Cane, Elsevier, Amsterdan, 133-309.

[59] Silva, L.C.F. and Casagrande, J.C. (1983) Mineral Nutrition of sugarcane (macronutrientes). In: Orlando Filho, J. Ed., Nutrition and Fertilization of Sugarcane in Brazil. IAA Planalsucar, Piracicaba, 77-99. (in Portuguese)

[60] Mascarenhas, H.A.A., Tanaka, R.T., Costa, A.A., Rosa, F.V. and Costa, V.F. (1994) Residual effects of legumes on the physical and economic yield of sugarcane. Instituto Agronômico, Campinas. (in Portuguese)

[61] Rochester, I. and Peoples, M. (2005) Growing vetches (Vicia Villosa Roth) in irrigated cotton systems: Inputs of fixed N, N fertilizer savings and cotton productivity. Plant and Soil, 271, 251-264.

http://dx.doi.org/10.1007/s11104-004-2621-1

[62] Silveira, J.A.G. and Crocomo, O.J. (1990) Nitrogen assimilation in sugarcane plants as affected by high levels of $\mathrm{N}$ and vinasse in the soil. Brazilian Journal of Plant Physiology, 2, 7-15.

[63] Freney, J.R., Denmead, O.T., Wood, A.W., Saffigna, P.G., Chapman, L.S., Ham, G.J., Hurney, A.P. and Stewart, R.L. (1992) Factors controlling ammonia loss from trash covered sugarcane fields fertilized with urea. Fertilizer Resarch, 31, 341-349. http://dx.doi.org/10.1007/BF01051285

[64] Gava, G.J.C., Trivelin, P.C.O., Vitti, A.C. and Oliveira, M.W. (2003) Recovery of nitrogen $\left({ }^{15} \mathrm{~N}\right)$ from urea and cane trash by sugar cane ratoon (Saccharum spp.). Brazilian Agricultural Research, 27, 621-630. (in Portuguese, with abstract in English)
[65] Trivelin, P.C.O., Rodrigues, J.C.S. and Victoria, R.L. (1996) Utilization by early harvest sugar cane ratoon of the nitrogen from ${ }^{15} \mathrm{~N}$-aqua ammonia and ${ }^{15} \mathrm{~N}$-urea applied to the soil as vinasse N-complement. Brazilian Agricultural Research, 31, 89-99. (in Portuguese, with abstract in English).

[66] Cantarella, H., Trivelin, P.C.O. and Vitti, A.C. (2007) Nitrogen and sulfur in the sugar cane. In: Yamada, T., Abdalla, S.R.S. and Vitti, G.C., Eds., Nitrogen and Sulfur in the Brazilian Agriculture, International Plant Nutrition Institute, Piracicaba, 355-412.

[67] Perin, A., Santos, R.H.S., Urquiaga, S., Guerra, J.G.M. and Cecon, P.R. (2006) Sunn hemp and millet as green manure for tropical maize production. Scientia Agricola, 63, 453-459. http://dx.doi.org/10.1590/S0103-90162006000500006

[68] Silva, E.C., Muraoka Buzetti, S., Veloso, M.E.C. and Trivelin, P.C.O. (2006) Utilization of nitrogen $\left({ }^{15} \mathrm{~N}\right)$ from sun hemp and millet by corn crop under no-tillage in Red Latosol of Cerrado. Rural Science, 36, 739-746. (in Portuguese, with abstract in English)

[69] Seo, J., Meisinger, J.J. and Lee, H. (2006) Recovery of nitrogen-15-labeled hairy veth and fertilizer applied to corn. Agronomy Journal, 98, 245-254. http://dx.doi.org/10.2134/agronj2005.0013

[70] Boaretto, A.E., Spolidoria, E.S., Freitas, J.G., Trivelin, P.C.O., Muraoka, T. and Cantarella, H. (2004) Fate of ${ }^{15} \mathrm{~N}$-urea applied to wheat-soybean succession crop. Bragantia, 63, 265-274. (in Portuguese, with abstract in English) http://dx.doi.org/10.1590/S0006-87052004000200011

[71] Basanta, M.V., Dourado Neto, D., Reichardt, K., Bacchi, O.O.S., Oliveira, J.C.M., Trivelin, P.C.O., Timm, L.C., Tominaga, T.T., Correchel, V., Cassaro, F.A.M., Pires, L.F. and Macedo, J.R. (2003) Management effects on nitrogen recovery in a sugarcane crop grown in Brazil. Geoderma, 116, 235-248.

http://dx.doi.org/10.1016/S0016-7061(03)00103-4

[72] Asagi, N. and Ueno, H. (2009) Nitrogen dynamics in paddy soil applied with various ${ }^{15} \mathrm{~N}$-labelled green manures. Plant and Soil, 322, 251-262. http://dx.doi.org/10.1007/s11104-009-9913-4

[73] Ghiberto, P.J.L., Libardi, P.L., Brito, A.S. and Trivelin, P.C.O. (2009) Leaching of nutrients from a sugarcane crop growing on an Ultisol in Brazil. Agricultural Water Management, 96, 1443-1448.

http://dx.doi.org/10.1016/j.agwat.2009.04.020 